\title{
Immunohistochemical Analysis of the Localization of Neuropeptides in the Adrenal Gland
}

\author{
Hisatake KONDO \\ Department of Anatomy (Prof. T. Fujita), Niigata University School of Medicine, Niigata, Japan
}

Received October 1 1, 1985

\begin{abstract}
Summary. Recent advances in immunohistochemical studies have revolutionalized our understanding of the adrenal gland with the discovery that many neuropeptides exist in the chromaffin cells and intraadrenal neuronal components. The coexistence of peptides and catecholamines is a constant feature of the chromaffin cells. The coexistene of multiple peptides is also seen in some chromaffin cells. This indicates that there are several subpopulations among the chromaffin cells in terms of bioactive substances contained. Diverging from the traditional view that intraadrenal nerves are predominantly preganglionic cholinergic ones innervating the chromaffin cells, the nerves are revealed to consist of heterogeneous populations containing various different neuropeptides. These are presumed to be of several different origins. The nerves innervate not only the chromaffin cells but partially the cortical cells, too, and are further associated with intraadrenal blood vessels. Several possible courses of action for the neuropeptides in the adrenal gland have been proposed based on immunohistochemical findings. The adrenal gland should be regarded as an endocrine organ, secreting not only catecholamines but also various neuropeptides; it likely plays more important and varied roles than previously believed for the maintainance of the internal environment of the body.
\end{abstract}

Immunological approaches over the past two decades have helped to greatly advance our understanding of the neuroanatomy of the central and peripheral nervous system. The production of antibodies specific for enzymes (rate limiting) involved in the synthesis of individual neurotransmitters has made it possible to identify neurons containing those transmitters by means of immunohistochemistry. A list of combinations of enzymes and related transmitters which to date have been identified by this methodology counts tyrosine hydroxylase $(\mathrm{TH})$ and catecholamines (CA), including dopamine (DA); noradrenaline (NA) and adrenaline (A); DA- $\beta$-hydroxylase (DBH) and NA; phenylalanine- $\mathrm{N}$-methyltransferase (PNMT) and A; glutamic acid decarboxylase (GAD) and $\gamma$-amino butylic acid (GABA); and choline acetyltransferase (ChAT) and acetylcholine (Ach) (BJörkLund and HökfELT, 1984). A logical expansion of the immunohistochemical approach using antibodies against transmitter-related enzymes was the attempt to produce antibodies against the transmitters themselves. The successful production of antibodies against transmitters with small molecules was made possible by coupling antigens with protein carriers, such as bovine serum albumin or thyroglobulin. Antibodies thus far obtained by means of this method include those against NA, A, 5-hydroxytryptamine (5-HT or serotonin), GABA, glutamate and even Ach 
(Steinbusch et al., 1978; Verhofstad et al., 1980; Storm-Mathisen et al., 1983; Geffard et al., 1985).

In addition to the broadening of our knowledge on the localization of the classical transmitters in this direction of the methodological approach, recent discoveries of a large number of neuropeptides in the central nervous system and the elucidation of their possible roles as new transmitters or neuromodulators have initiated the intensive analysis of the localization and neuronal circuits of peptide-containing neurons by immunohistochemistry, using antibodies against the neuropeptides. As a consequence, unexpectedly wide distributions of neuropeptides, the coexistence of classical transmitters and neuropeptides or of more than two peptides in single neurons, and new pathways of neuronal circuits have been revealed in the central and peripheral nervous system (HökfEL T et al., 1980, 1984). In the autonomic ganglia, for example, more than ten neuropeptides have been ascertained. The coexistence of peptides with NA or Ach, and the existence of neuronal connections between the autonomic ganglia and the spinal sensory ganglia or the intramural ganglia of the gut wall have also been demonstrated (Kondo, 1983; SchultzBerg et al., 1983). Thus, these findings led us to consider mechanisms more complicated than those so far supposed for the pathways of excitation and inhibition in the autonomic ganglion.

Such is also the case in the adrenal medulla, which is homologous to the autonomic ganglia in its ontogeny. According to the classical view, the adrenal chromaffin cells produce and secrete CA under the control of the preganglionic cholinergic nerves, whose cell somata are located in the intermediate gray matter of the lower thoracic and upper lumber spinal cord (Coupland, 1965). However, the recent discoveries of various neuropeptides in the adrenal gland have somewhat complicated our previous understanding of the nature of this organ. The present article reviews the immunohistochemical findings, at the light and electron microscopic levels, on the localization in the adrenal gland of the neuropeptides and some biogenic amines other than CA. The functional implications of the neuropeptides in the adrenal endocrine nature will be also discussed.

\section{OCCURRENCE OF PEPTIDES IN CHROMAFFIN CELLS}

\section{Opioid peptides}

Methionine (Met)-enkephalin (ENK) and leucine (Leu)-ENK are endogenous pentapeptides having an opioid activity; they were originally discovered in the brain (Hughes et al., 1975). These peptides are also the first ones to have been identified and extensively studied in the adrenal chromaffin cells by immunohistochemistry (SchultzBerg et al., 1978). It has been clarified by cloning and sequence analysis of cDNA that various opioid peptides are generated by the post-translational processing of either one of three precursors: preproenkephalin, preprodynorphin or proopiomelanocortin (NAKANishi et al., 1979; KAKIdANi et al., 1981; NodA et al., 1982). Met-ENK is included in the amino acid sequence of both preproenkephalin and proopiomelanocortin, while Leu-ENK is included in both preproenkephalin and preprodynorphin. On the other hand, Met-ENK-arginine ${ }^{6}(\mathrm{Arg})$-glycine ${ }^{7}(\mathrm{Gly})-\mathrm{leucine}^{8}(\mathrm{Leu})$ and Met-ENK-Arg-6. phenylalanine ${ }^{7}$ (Phe), newly identified as opioid octa- and penta-peptides (STERN et al., 1979; KILPATRICK et al., 1981) are contained solely in preproenkephalin. Therefore, the demonstration of Met-ENK-Arg-Gly-Leu-like immunoreactivity indicates the existence of preproenkephalin and all its derivatives, including Met- and Leu-ENK. 


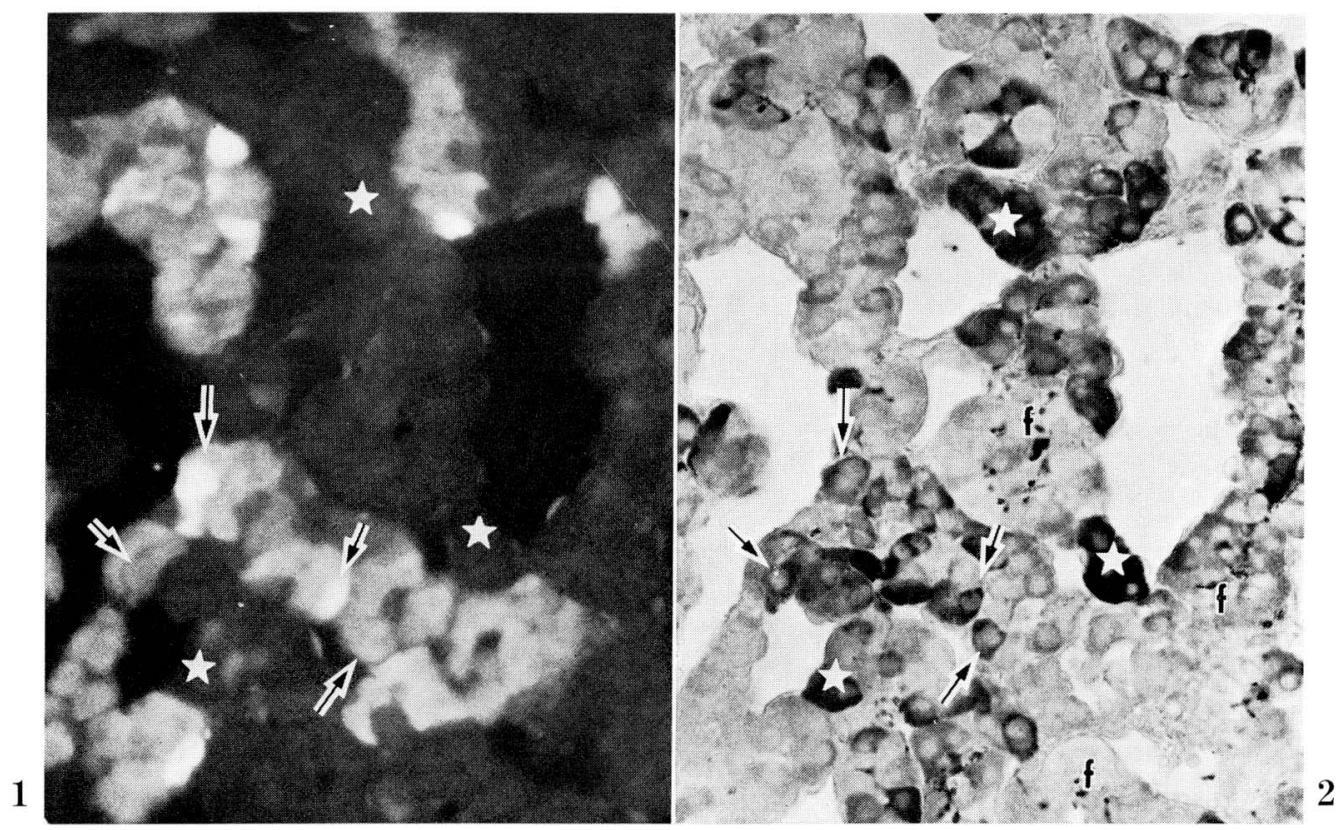

Fig. 1 and 2. Light micrographs of one and the same section of the rat adrenal medulla shown by formaldehyde-induced fluorescence microscopy (Fig. 1) and by immuno-histochemistry for MetENK-Arg-Gly-Leu (Fig. 2). Some ENK-immunoreactive chromaffin cells (asterisks) are nonfluorescent for noradrenaline, indicating the coexistence of ENK with A, while others (arrows) emit strong fluorescence, indicating the coexistence of ENK with NA. Note abundant ENKnerve fibers $(f)$ with varicose or dotted appearance among the chromaffin cells. $\times 270$

To date, Met-ENK-like immunoreactivity has been demonstrated in adrenal chromaffin cells in-situ of many mammals including rats, guinea pigs, dogs, cats, pigs, bovines, horses and men (SchultzBerg et al., 1978; Linnoila et al., 1980; LivetT et al., 1982; VARNDELL et al., 1982) and some submammalian species such as frogs (Leboulenger et al., 1983; Kondo and Yui, 1984). Leu-ENK-like immunoreactivity has been shown in the in-situ chromaffin cells of rats, guinea pigs, hamsters, cats, bovines and men (SchultzBerg et al., 1978; Hervonen et al., 1980; Linnolla et al., 1980; Livett et al., 1982; Pelto-Huikko et al., 1982). Met- and Leu-ENK-like immunoreactivities have also been detected in the cultured chromaffin cells of bovines (LivETT and Dean, 1980; Livet et al., 1981; Siegel et al., 1985). In addition, Met-ENK-Arg-GlyLeu-like and Met-ENK-Arg-Phe-like immunoreactivities have been demonstrated in the adrenal chromaffin cells of rats, dogs, cats and monkeys (Fig. 1) (KoBAyAsHI et al., 1983a, b; Kondo et al., 1984). No positive cells have been found in the adrenal medulla of most mammals to immunoreact with antisera against $\alpha$-, $\beta$-endorphin, $\gamma$-MSH (melnocyte stimulating hormone), $\beta$-LPH (lipotropic hormone) or ACTH (adrenocorticotropic hormone) (SchultzBerg et al., 1978), although the occurrence of ACTHimmunoreactive cells was reported only in the fetal adrenal medulla at the 23rd week of gestation (ITO et al., 1981). No immunohistochemical studies have yet been reported suggesting the presence of preprodynorphin and its derivatives such as neo-endorphin and dynorphin in the adrenal medulla, although a distinct distribution of dynorphinlike immunoreactivity was described in isolated bovine adrenal chromaffin cells by radioimmunoassay (Dumont et al., 1983). It is, therefore, highly possible that opioid 
peptides in the adrenal medulla are predominantly generated by posttranslational processing of preproenkephalin as a common precursor.

The population of the ENK-immunoreactive chromaffin cells varies by species. For example, most chromaffin cells are ENK-immunoreactive in cats, as are a large proportion of those in guinea pigs, and a small number (20-25\%) in rats (SchUlTzBERG et al., 1978; Kondo et al., 1984). The intensity of the immunoreaction also varies among immunoreactive chromaffin cells (Fig. 1). There have been several reports indicating that the appearance of the ENK-like immunoreactivity may depend on the experimental conditions (SchultzBerG et al, 1978; Lewis et al., 1981; BoHN et al., 1983). In the above studies, the severance of the splanchnic nerve innervating the rat adrenal medulla resulted in the appearance of a large proportion of chromaffin cells. The treatment of rats with nicotinic blocking agents such as chlorisondamine or pempidine also induced a dramatic increase in the number of ENK-immunoreactive chromaffin cells. These findings suggest that the levels of ENK-like immunoreactivity in the chromaffin cells are subject to transsynaptic regulation. An increase of ENK-like immunoreactivity was also induced in bovine chromaffin cells in culture after treatment with forskolin, a potent stimulator of adenylate cyclase (SIEGEL et al., 1985).

By means of immunohistochmistry using both anti-ENK antiserum and antisera against DBH and PNMT, SchultzBerG et al. (1978) were first to show ENK-immunoreactive chromaffin cells in the rat as immunopositive for $\mathrm{DBH}$ but negative for PNMT. This finding indicates that ENKs are contained in the NA-chromaffin cells. The same authors further showed that denervation resulted in the additional appearance of ENK-like immunoreactivity in a population of PNMT-positive chromaffin cells. They concluded, therefore, that both NA- and A-cells in the rat basically contained ENKs. They also maintained that the same was true in guinea pigs and cats, as an ENK-like immunoreactivity occurred in the majority of the chromaffin cells, including both NA- and A-cells. Other evidence in support of the coexistence of ENK with both NA and A was presented by KoBAYAshi et al. (1983a), who continued this point of investigation in rats, dogs and cats by means of immunohistochemistry using antisera against Met-ENK-Arg-Gly-Leu or Met-ENK-Arg-Phe, and NA and A. The same conclusion was obtained by the present authors using a combination of immunohistochemistry with formaldehyde-induced fluorescence microscopy (Fig. 1, 2). In contrast, there have been several reports indicating the coexistence of ENK and A, but not NA, in the adrenal chromaffin cells of hamsters and bovines by a combination of immunohistochemistry with formaldehyde-induced fluorescence microscopy or by immunohistochemistry with antisera against ENKs, DBH and PNMT (LivetT et al., 1982; PeltoHuikкo et al., 1982). From a phylogenic viewpoint the coexistence of ENK and A has also been shown in chromaffin cells of the frog adrenal gland (Kondo and YUI, 1984). These different results on the coexistence are difficult to reconcile at present, but might indicate that there are widespread strain or species differences in the level of ENKs in chromaffin cells.

Immuno-electron microscopic studies using PAP (peroxidase anti-peroxidase) labelling, or immuno-globulin- or protein A-gold labelling have shown that the immunoreaction product for ENKs is localized precisely on the core of the chromaffin granules (Hervonen et al., 1980; Varndell et al., 1982; Kobayashi et al., 1983b; Kondo and Yui, 1984; Kondo et al., 1984). This suggests that ENKs are released together with CA via exocytosis. In accord with the fine structural findings, there has been accumulating evidence to indicate the co-release of ENKs together with CA from the adrenal chromaffin cells in vivo and in vitro (Viveros et al., 1979; Clement-Jones et al., 1980; 

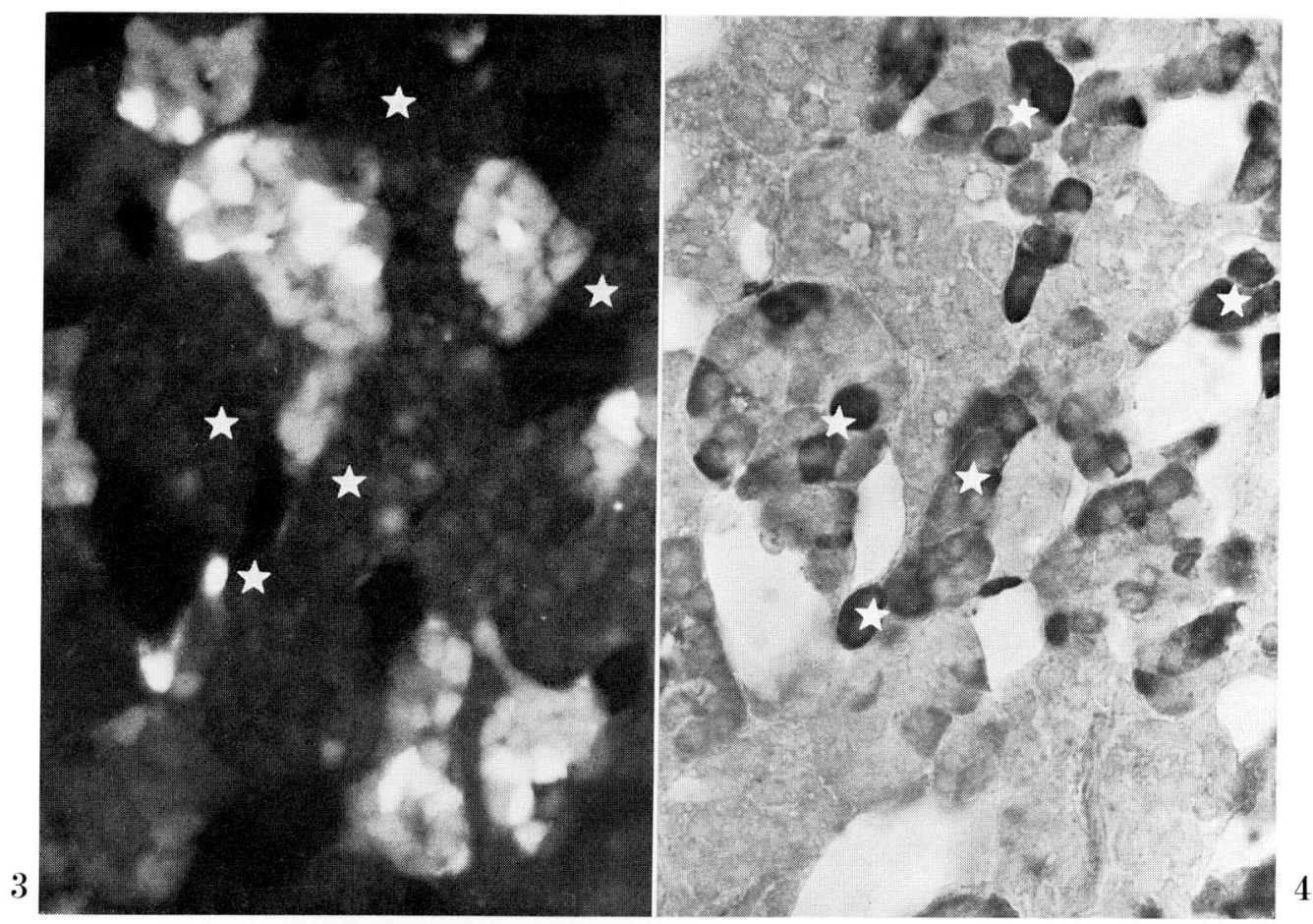

Fig. 3 and 4. Light micrographs of one and the same section of the rat adrenal medulla shown by formaldehyde-induced fluorescence microscopy (Fig. 3) and by immunohistochemistry for NPY (Fig. 4). All the immunoreactive chromaffin cells (asterisks) are non-fluorescent, indicating the coexistence of NPY with A. $\times 285$

Kilpatrick et al., 1980; Viveros et al., 1980; Corder et al., 1982; Viveros 1983). In cultured bovine chromaffin cells without innervating nerves, ENKs and CA have been shown to be released together by nicotine in a $\mathrm{Ca}^{++}$-dependent manner (LivetT et al., 1981).

\section{NPY (neuropeptide tyrosine)}

NPY is a thirty-six amino acid peptide with a characteristic carboxy terminal tyrosine amide group. Although NPY has striking homologies in its amino acid sequence with two other peptides originally isolated from the pancreatic islets, pancreatic polypeptide (PP) and peptide with tyrosine (PYY), it has been shown to exist solely in the neuronal tissues of mammals (Tатемото, 1982; Tатемото et al., 1982; Emson and De Quidt, 1984).

The occurrence of NPY-like immunoreactivity in the adrenal chromaffin cells has been demonstrated in mice, rats, guinea pigs, cats and horses (VARNDELL et al., 1984; Kuramoto et al., 1985b). High concentrations of NPY were extracted from the mouse adrenal gland (up to $1,263.7 \pm 122.8 \mathrm{pmol} \mathrm{NPY/g}$ tissue) and a chromatographic analysis of the mouse adrenal extract showed that the NPY-like immunoreactivity co-elutes in the position of porcine NPY standard at 45\% acetonitrile. These findings indicate that the NPY-immunoreactive substance is authentic NYP. Our recent immunohistochemical study has demonstrated that in the rat adrenal medulla, approximately $50 \%$ of the total chromaffin cells exhibited NPY-like immunoreactivity (KURAmoto et al., 1985b). 

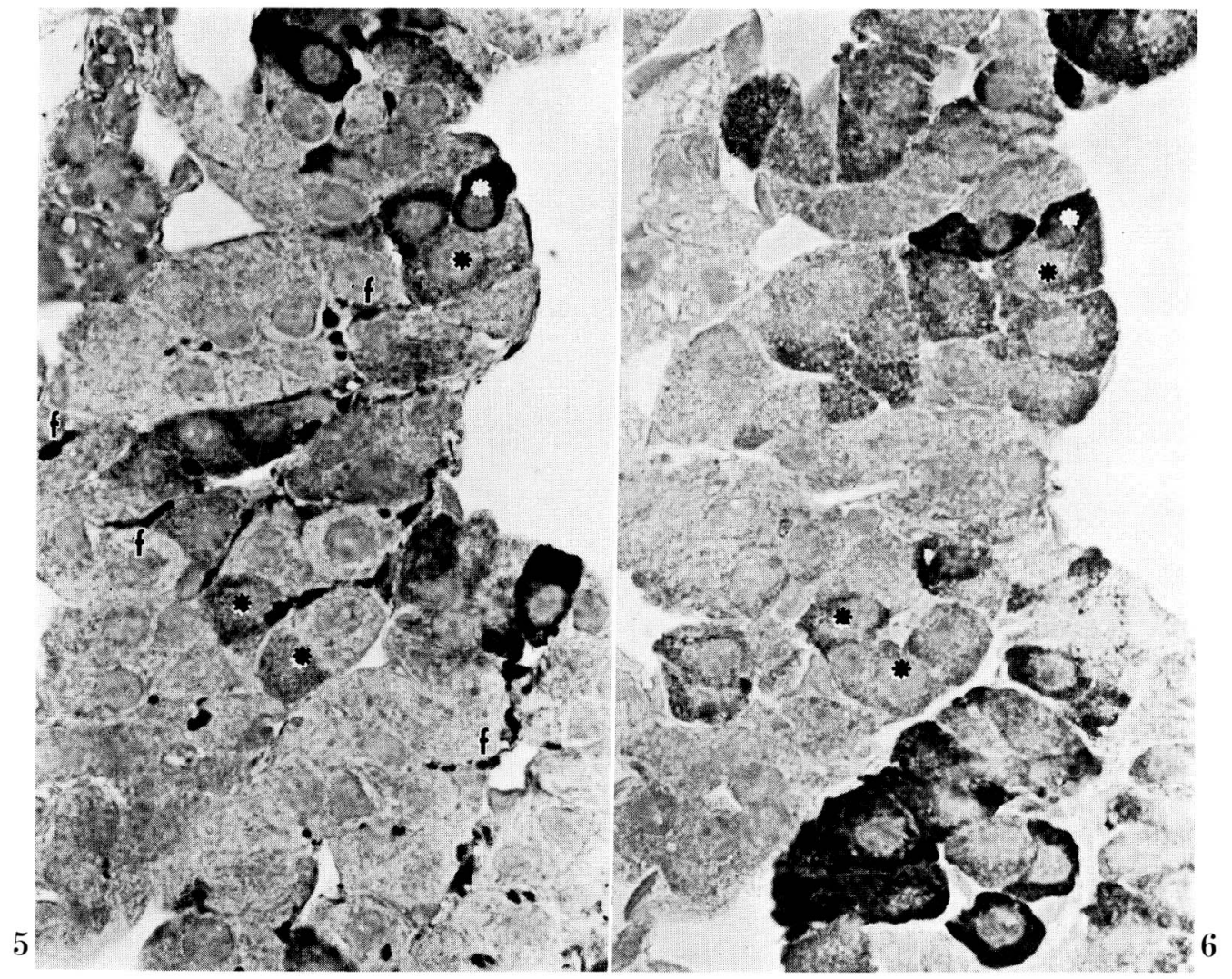

Fig. 5 and 6. Immunohistochemicel micrographs of two serial sections of the rat adrenal medulla incubated with anti-NPY antiserum (Fig. 5) and with anti-Met-ENK-Arg-Gly-Leu antiserum (Fig. 6), respectively. Some chromaffin celle (asterisks) exhibit a positive immunoreaction for both of the antisera, indicating the coexistence of NPY and ENK. $f$ ENK-immunoreactive fibers. $\times 660$

There is a discrepancy in conclusions regarding the coexistence of NPY with CA Through a combination of immunohistochemistry with formaldehyde-induced fluorescence microscopy, our immunohistochemical study clearly demonstrated that all NPYimmunoreactive chromaffin cells were non-fluorescent for NA in the rat adrenal medulla, leading us to conclude that NPY coexisted with A in the chromaffin cells (Fig. 3, 4) (Kuramoto et al., 1985b). In contrast, Varndell et al. (1984) was able to show the fine structural difference lying between NPY-positive chromaffin granules labelled with colloidal gold and NPY-negative granules in the horse adrenal medulla, and stressed the coexistence of NPY with NA. According to the fine structural criteria for the identification of chromaffin granules in specimens fixed with glutaraldehyde and osmium tetroxide, NA-granules are characterized by solid cores of high electron density which often are irregular in shape and located eccentrically. A-granules, on the other hand, have rounded cores with moderate electron density (Coupland, 1965). However, in electron microscopic immunohistochemical study by VARNDELL et al. (1984), the specimens were fixed only with aldehydes; therefore, the resulting images did not show any difference in electron density of two types of granules, although the irregular shape of the granule core was evident in 'NA-granules' of the horse adrenal 
medulla. The identification of the two cell types in their study, therefore, seems to be less reliable than that by formaldehyde-induced fluorescence microscopy or by immunohistochemistry with CA-synthesizing enzymes. This is one of the plausible explanations for the discrepancy. Alternatively, this discrepancy might be simply due to species difference, as in the case of ENK described above. In addition, it is interesting to note that the coexistence of NPY with A in the rat chromaffin cells is in contrast to the coexistence of NPY with NA in the sympathetic postganglionic neurons of rats and other mammals (LundBeRg et al., 1985; Mattiasson et al., 1985), in spite of the homologous origin for the ontogeny of both cell types.

It was demonstrated in our study that NPY coexisted with preproenkephalin and its derivatives in approximately one tenth of the total chromaffin cells of the rat adrenal medulla (Fig. 5, 6) (KuRAmoto et al., 1985b). This result indicates that the three biologically active substances, NPY, ENK and A, are jointly stored in a substantial number of the adrenal chromaffin cells.

In electron microscopic immunohistochemistry NPY was localized rather precisely on the cores of the chromaffin granules (VARNDELl et al., 1984; KuRAmoto et al., 1985b). This suggests the simultaneous release of NPY together with CA by exocytosis. Although it has been shown that plasma samples from patients with pheochromocytomas contained greatly elevated NPY levels (ADRIAN et al., 1983), little is known yet about the mechanisms of the release of NPY from the normal chromaffin cells in vivo and in vitro.

\section{Substance $\mathbf{P}$}

Substance $P$ is an undecapeptide for which the idea of peptidergic neurotransmission was first proposed in the spinal cord (LemBeck, 1953; Otsuka and Konishi, 1976). The presence of immunoreactive substance $P$ has been shown by radioimmunoassay in the adrenal medulla of rats, rabbits, guinea pigs, bovines and men (SARIA et al., 1980; Bucsics et al., 1981; RoLE et al., 1981). Chemical analyses of bovine chromaffin granules have shown a measured immunoreactivity corresponding to authentic substance $P$, which suggests the localization of substance P in some chromaffin cells (Bucsics et al., 1981). Our recent immunohistochemical studies both at the light and electron microscopic levels have confirmed the presence of a small number (several cells in single random sections cut through the maximum diameter of the adrenal medulla) of substance P-immunoreactive chromaffin cells in the rat adrenal medulla (KuRAmoto et al., 1985a). These immunoreactive cells occurred alone or in small groups, were polygonal in shape and had no cytoplasmic processes. The cells contained abundant chromaffin granules having a concentric, round core, which are considered to be a characteristic feature of A-containing chromaffin cells (Coupland, 1965). The immunoreactive material was confined to the cores in most granules (Fig. 16), suggesting that substance $\mathrm{P}$ coexists and is secreted simultaneously with $\mathrm{A}$ in the rat adrenal medulla. It is necessary to confirm this possible coexistence by a combination of immunohistochemistry with formaldehyde-induced fluorescence microscopy, or by simultaneous immunohistochemistry for both substance $\mathrm{P}$ and CA synthesizing enzymes.

\section{VIP (vasoactive intestinal polypeptide)}

VIP is a strongly basic octacosapeptide which was originally isolated from the porcine duodenum, but is now known to be widely distributed in the nervous system (MUTT and SAid, 1974; FAhrenkrug, 1980). Extracts from the porcine and human adrenal glands have shown by radioimmunoassay only one peak of VIP-like immunoreactivity 


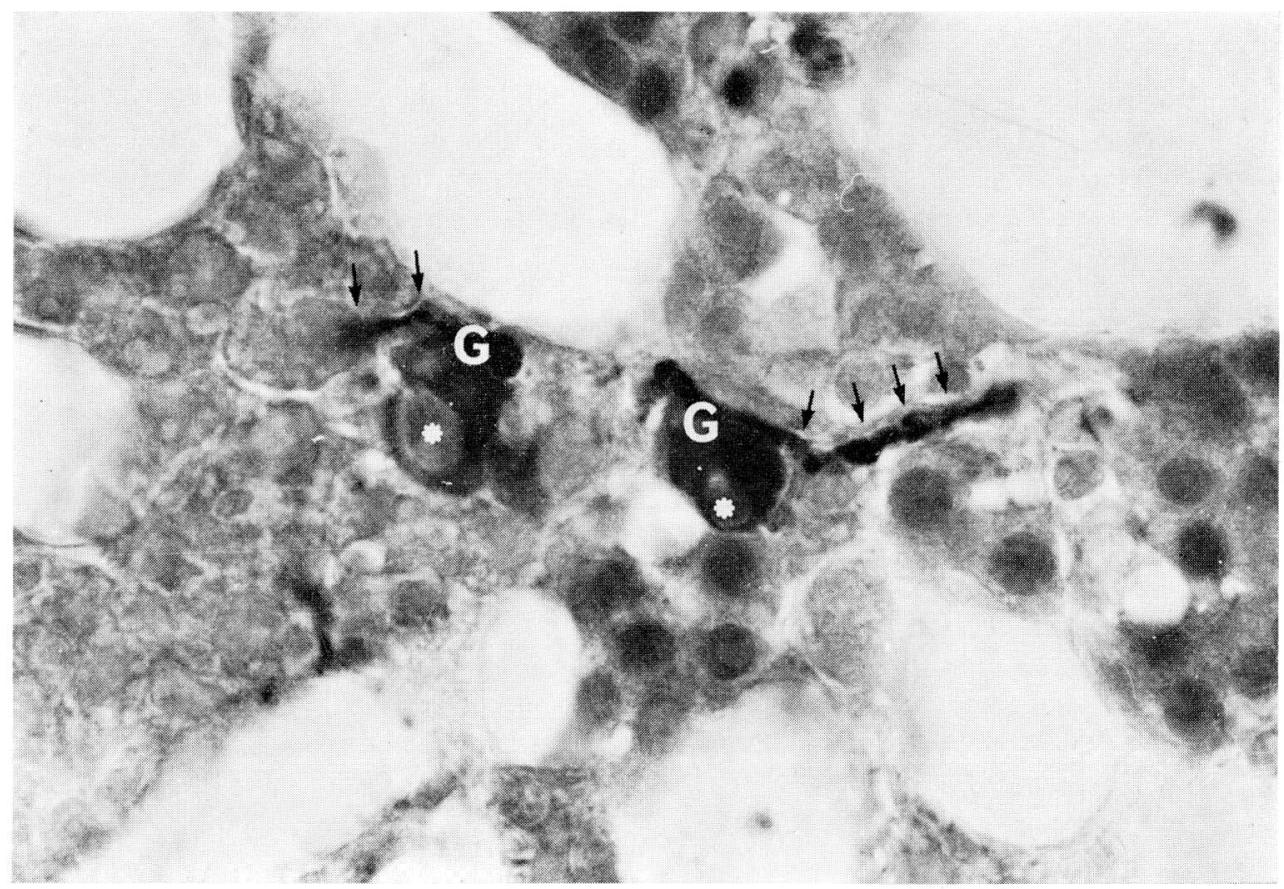

Fig. 7. An immunohistochemical micrograph of vecuolated ganglion cells $(G)$ exhibiting a positive reaction for VIP among non-reactive chromaffin cells of the rat adrenal medulla. VIPganglion cells have large vacuoles (asterisks) and send long processes as nerve fibers (arrows) $\times 830$
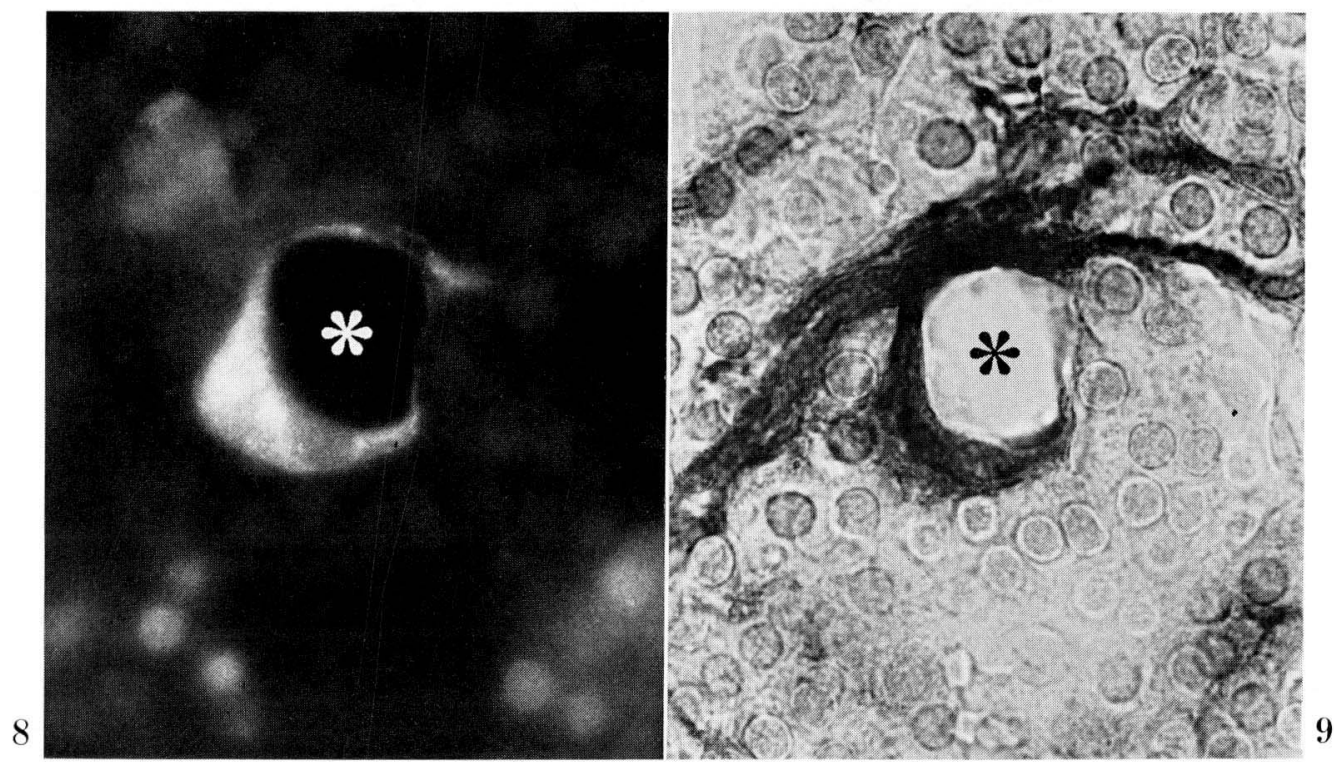

Fig. 8 and 9. An immunofluorescence micrograph of a vacuolated ganglion cell immunoreactive for VIP (Fig. 8) and a micrograph showing an intensely positive AchE reaction of the vacuolated ganglion cell (Fig. 9) in one and the same section of the rat adrenal medual medulla. Large intracytoplasmic vacuole are indicated by asterisks. $\times 620$ 


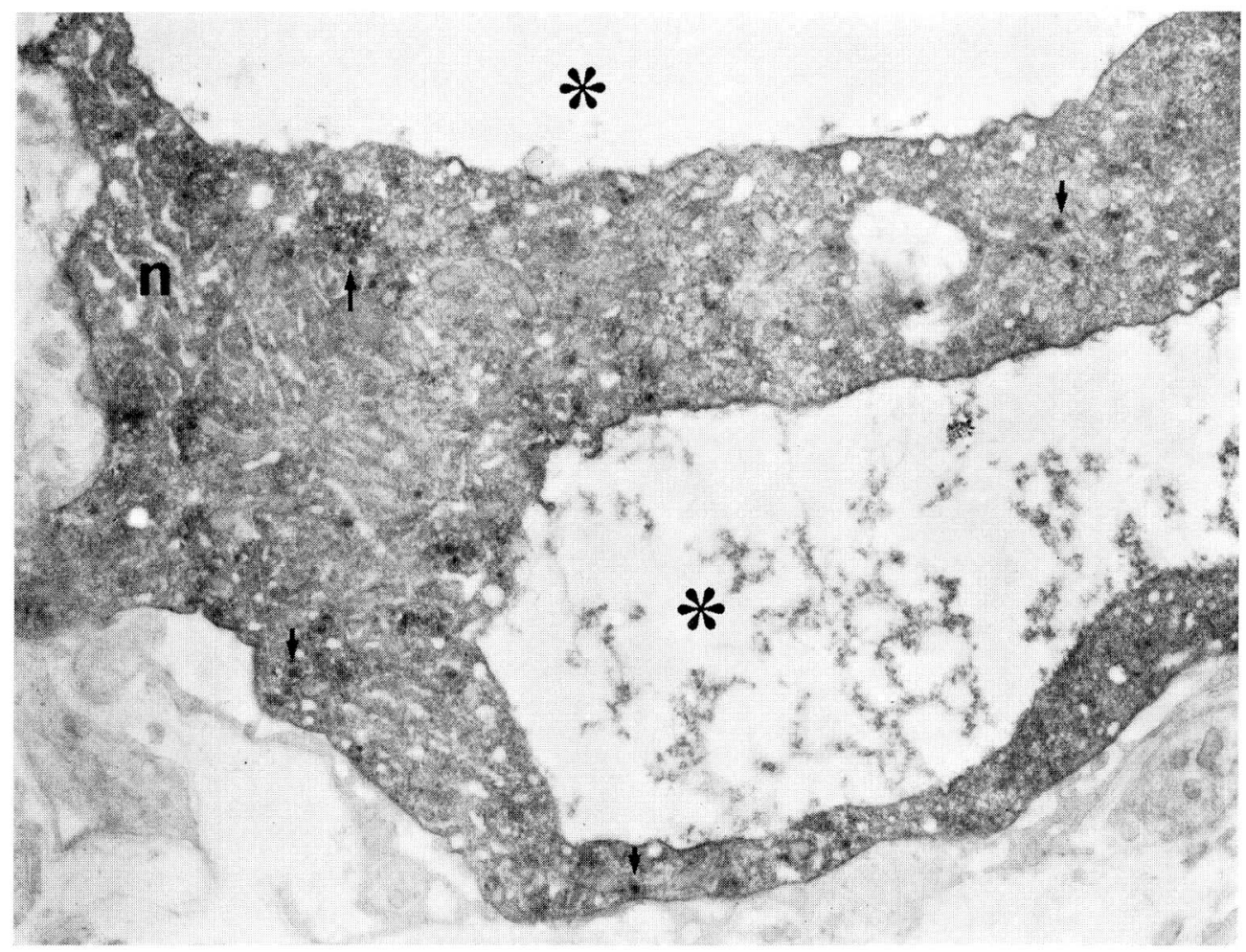

Fig. 10. An electron micrograph of a VIP-ganglion cell soma of the rat adrenal medulla. Well developed cisterns of rough endoplasmic reticulum $(n)$ and abundant free rebosomes are dominant but a few large granular vesicle (arrows) are scattered in the cytoplasm. Note the immunoreaction products localized in the granule cores as well as occurring diffusely in the cytoplasm. Large intracytoplasmic vacuoles indicated by asterisks contain flocculent material $\times 9,100$

which was indistinguishable from pure porcine VIP (BRyAnT et al., 1976). A substantial amount of VIP has also been measured by radioimmunoassay from a cultured medium for isolated bovine adrenal chromaffin cells after 1 or 3 days of culturing, although VIP was not detectable in freshly dissociated cells (EIDEN et al., 1983; SiegeL et al., 1985).

Immunohistochemical studies have disclosed the occurrence of a small number of VIP-immunoreactive cells in the adrenal medulla of rats and men (BRYANT et al., 1976; HöKfElt et al., 1981; Holzwarth, 1984). Recently, our electron microscopic immunohistochemistry in the rat adrenal medulla has confirmed that some of the VIP-positive cells are true chromaffin cells (Kondo et al., in preparation). In our study, VIP-positive chromaffin cells were fewer than substance P-positive chromaffin cells of the same species, and occurred separately. The VIP-positive cells were polygonal in shape without any cytoplasmic processes and contained abundant chromaffin granules having a round core. The immunoreactive material was confined to the core of most granules. It is therefore suggested that VIP and A are jointly stored and released by exocytosis. It was also shown that a small number of VIP-positive cells was present in the bovine chromaffin cells in cultures maintained for 3 days, and that about $70 \%$ of the VIPpositive cells in culture also stored ENKs (Siegel et al., 1985). This study also demon- 


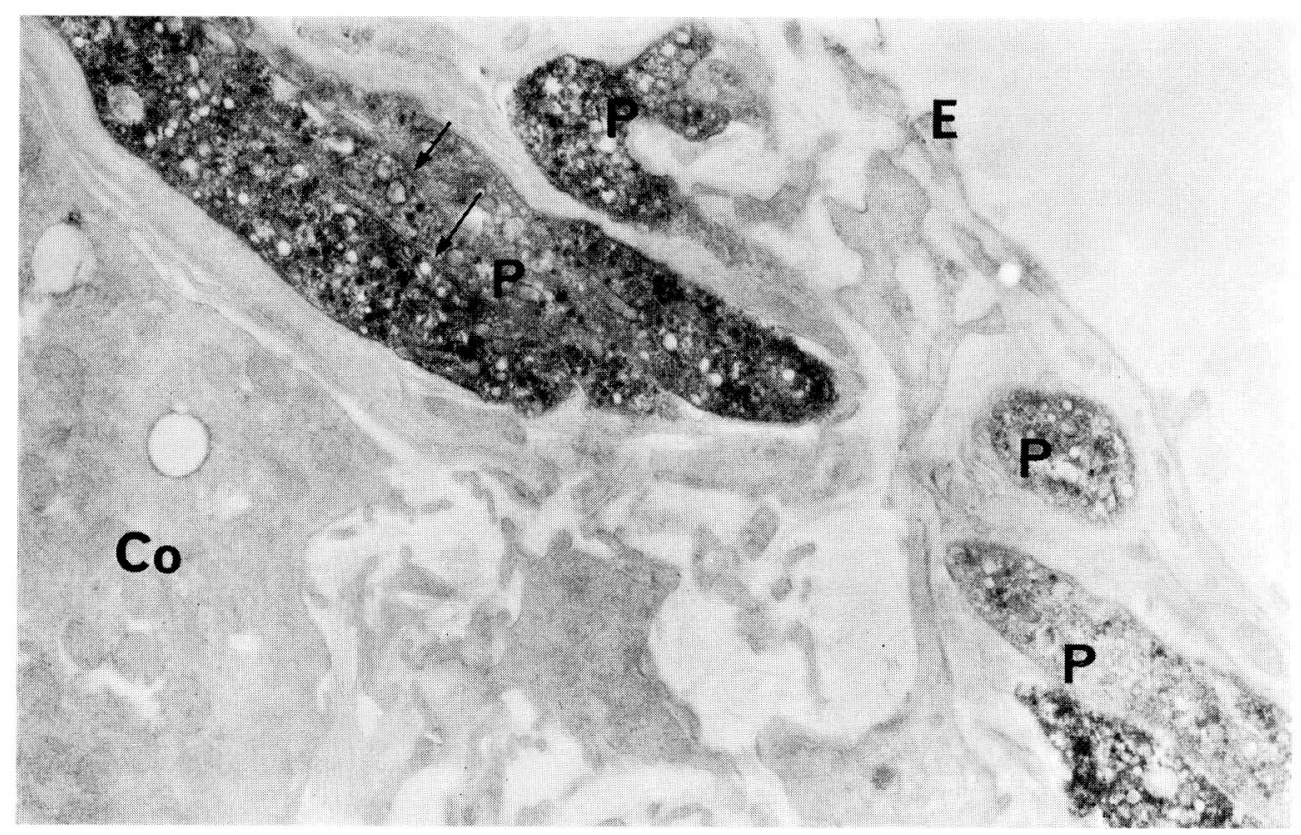

Fig. 11. An electron micrograph of VIP-immunoreactive ganglionic processes $(P)$ running in the juxtamedullary cortex of the rat adreanl gland. Note the direct contact between adjacent processes (arrows). Co cortical cell, $E$ endothelial cell. $\quad \times 9,000$
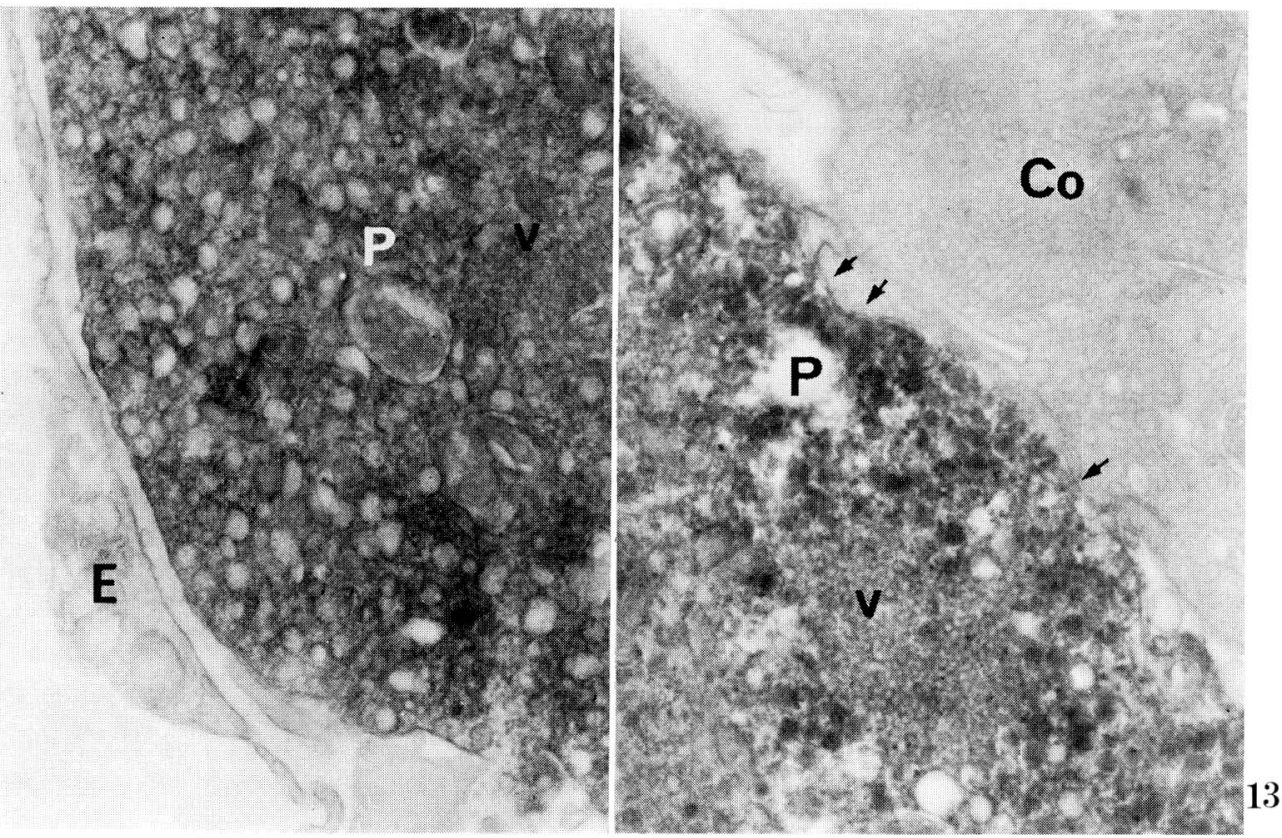

Fig. 12 and 13. VIP-immunoreactive ganglionic process $(P)$ in close apposition to a fenestrated endothelial cell $(E)$ intervening a common basal lamina (asterisks) in Fig. 12 and in direct contact (arrows) with a cortical cell $\left(\mathrm{Co}_{0}\right)$ in Fig. 13. Note the presence of abundant large granular and clear vesicles and small clear vesicles $(V)$ in the VIP-ganglionic processes, and the immunoreactive material localized in the granule cores as well as occurring diffusely in the axoplasm. $\times 23,000$ 
strated that the addition of forskolin, a potent stimulator of adenylate cyclase, to the culture medium increased the number of the VIP-positive cells. Among submammalian species, the frog adrenal gland has also been examined by immunohistochemistry (LEBOULENGER et al., 1983). According to their study, most chromaffin cells exhibited VIP-like immunoreactivity and almost half of them simultaneously exhibited ENK-like immunoreactivity.

\section{Somatostatin}

Somatostatin, originally discovered as a growth hormone release-inhibiting factor in the hypothalamus (KRULICH et al., 1973), was also isolated from sheep hypothalamic tissues and characterized as a tetradecapeptide (BRAZEAU et al., 1973). The presence of somatostatin-like immunoreactive material was shown by radioimmunoassay in extracts from the adrenal gland and of purified chromaffin cells of guinea pigs and cats (Role et al., 1981; CoRDER et al., 1982). Single somatostatin-immunoreactive chromaffin cells have so far been observed by immunohistochemistry only in the human adrenal medulla (LUNDBERG et al., 1979). No data are available at present on the fine structure of somatostatin-immunoreactive chromaffin cells.

\section{Neurotensin}

Neurotensin is a tridecapeptide originally isolated and characterized in the bovine hypothalamus (CARRAwAY and LeEman, 1973, 1975). Neurotensin-like immunoreactivity has been found by radioimmunoassay in the adrenal medulla of rats, guinea pigs, rabbits, cats and bovines, among which the highest level was seen in the cat (CORDER et al., 1982; LundBerg et al., 1982; Goedert and Emson, 1983; GoederT et al., 1983). In a chromaffin granule preparation from the bovine adrenal medulla, neurotensin-like immunoreactivity was concentrated in a manner identical to CA (GoEDERT et al., 1983).

Immunohistochemical studies have demonstrated the localization of neurotensinlike immunoreactivity in a subpopulation of NA-chromaffin cells, i.e. the DBH-positive and PNMT-negative cells of cats (LunDBEG et al., 1982; TERENGHI et al., 1983). The immunoreactive cells were revealed to contain pleomorphic, electron dense granules in their cytoplasm and the immunoreactive material was confined to the core of the granules, suggesting the release of neurotensin together with NA by exocytosis. In support of this suggestion, $\mathrm{Ca}++$-dependent release of neurotensin has been demonstrated in perfused adrenal glands of the cat (CORDER et al., 1982).

\section{CGRP (calcitonin gene-related peptide)}

The advent of recombinant DNA technology has revealed alternative processing of RNA transcripts from the calcitonin gene, resulting in the production of distinct mRNAs encoding calcitonin or the calcitonin gene-related peptide (CGRP) (AMARA et al., 1982). This 37 amino acid CGRP, which is not homologous in the amino acid sequence with calcitonin, has subsequently been shown by radioimmunoassay and immunohistochemistry to be localized in different areas of the nervous system (ROSENFELD et al., 1983; Gibson et al., 1984; Mulderry et al., 1985).

The occurrence of CGRP-like immunoreactivity in chromaffin cells was first revealed by immunohistochemistry in the rat adrenal medulla (RosENFELD et al., 1983). A recently performed detailed study on the localization of CGRP-like immunoreactivity in the rat adrenal medulla (КURAмото et al., in preparation) showed immunoreactive cells to be small in number, but slightly more numerous than the substance P-positive 


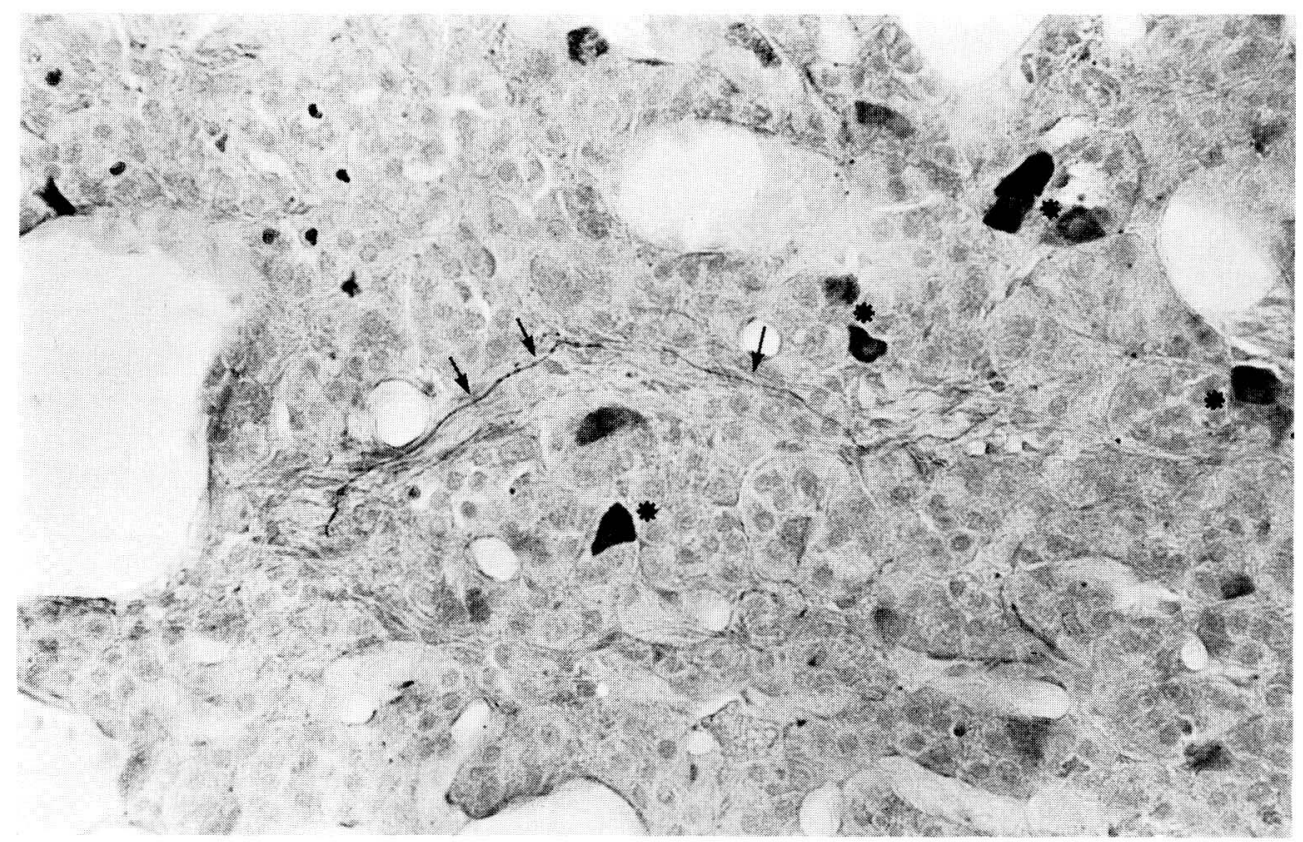

Fig. 14. An immunohistochemical micrograph showing CGRP-positive chromaffin cells (*) and nerve nerve fibars (arrows) in the rat adrenal medulla. $\times 310$

chromaffin cells (Fig. 14). They occurred singly and had no cytoplasmic processes. By combination of immunohistochemistry with formaldehyde-induced fluorescent microscopy, the CGRP-positive cells were revealed to contain adrenaline. The coexistence of CGRP with ENKs or NPY was also detected in some of the CGRP-positive chromaffin cells.

\section{Biogenic amines other than catecholamines}

It has been generally believed that the biogenic amines released from the adrenal chromaffin cells are NA and A. However, there have been several reports suggesting the presence of other biogenic amines such as serotonin and histamine in the adrenal medulla (Bertleer et al., 1960; Baráth and Csabe, 1973; Csaba and BarÁth, 1974; Endo and Ogura, 1974; Csaba and Sudár, 1978; Sudár and Csaba, 1979). The exact localization of these amines has recently been clarified in the rat adrenal medulla by means of immunohistochemistry using specific antisera against serotonin and histamine (VERHofstad and Jonsson, 1983; HÄPPÖLÄ et al., 1985). Serotonin-like immunoreactivity was confined to the A-chromaffin cells identified by anti-A antiserum. Histaminelike immunoreactivity was detected in the NA-chromaffin cells identified by formaldehyde-induced fluorescence. Since treatment with L-tryptophan or tryptophan hydroxylase inhibitor $\mathrm{H} \mathrm{22/54}$ resulted in no change in the level of serotonin in the adrenal gland, and because the administration of 5-hydroxytryptophan led to a marked increase of the serotonin level, it is suggested that the serotonin present in the Achromaffin cells is derived from circulating serotonin and/or 5-hydroxytryptophan. Since no evidence is available on the location in the adrenal medulla of histidine decarboxylase, the enzyme converting histidine to histamine, it remains unknown whether histamine is synthesized in NA-chromaffin cells or taken up from the circulation. 


\section{OCCURRENCE OF PEPTIDES IN GANGLION CELLS}

The adrenal medulla of many mammalian species contains scattered groups of ganglion cells. The proportion of ganglion cells to chremaffin cells varies from species to species although in general, only slightly, (Coupland, 1965). The presence of vacuolated ganglion cells in the adrenal medulla of some mammalian species such as hamsters and rats has been known for sometime (UNSICKER, 1969; Kondo et al., 1985). These cells contain intracytoplasmic vacuoles, $8-30 \mu \mathrm{m}$ in diameter, delineated with a single unit membrane. Flocculent material is often seen inside the vacuoles in electron microscopy (Fig. 10).

The cytoplasmic features of both non-vacuolated and vacuolated ganglion cells at the ultrastructural level are basically the same as those of ordinary autonomic ganglion cells (GRILlo, 1966). Their perikarya receive synaptic contact with nerve fibers containing abundant small clear vesicles mixed with some large granular vesicles. The perikaryal surface is covered with a satellite cell sheath, though its covering is incomplete unlike the ordinary ganglion cells, and some surface areas are directly exposed to the interstitial space with only a basal lamina intervening. Histochemical studies for acetylcholinesterase and the uptake of 5-hydroxydopamine have inferred that both cholinergic and noradrenergic ganglion cells are present in the adrenal medulla (LEwIS and Shuth, 1969; Unsicker et al., 1977). However, the interrelation of the ganglionic processes with adjacent cellular and vascular elements has remained little understood.

Recent immunohistochemical studies have revealed the presence of VIP-immunoreactive ganglion cells in the rat adrenal medulla (BRYANT et al., 1976; HöKFELT et al., 1981; HolzWARTH, 1984) and our immunohistochemical study at the light and electron microscopic levels (Kondo et al., 1985) has detailed the features of the immunoreactive ganglion cells in the same species (Fig. 7-13). Most of these immunoreactive cells were vacuolated and sent long processes among the chromaffin cells and juxtamedullary cortical cells. The neuronal processes changed thickness $(0.3-2.5 \mu \mathrm{m}$ in diameter $)$ along their trajectories. In electron microscopic immunohistochemistry, the VIP-ganglion cells had a round nucleus poor in chromatin and contained an extensively developed Golgi apparatus, cisterns of rough endoplasmic reticulum and free ribosomes; only a few granular vesicles, $90-120 \mathrm{~nm}$ in diameter were scattered in the periphery of the perikaryal cytoplasm. Neuronal processes of the VIP-ganglion cells were characterized by numerous large clear vesicles, $90-150 \mathrm{~nm}$ in diameter, as well as large granular vesicles, $90-120 \mathrm{~nm}$ in diameter, and small clear vesicles, $40-55 \mathrm{~nm}$ in diameter. The immunoreactive material appeared not only in the cores of the granular vesicles but also diffusely in the cytoplasm of both perikarya and their processes.

The VIP-immunoreactive ganglionic processes were often denuded of Schwann cell sheaths to a varying degree. The denuded portions were located in close apposition to fenestrated endothelial cells in the medulla and juxtamedullary cortex with a minimum distance of $70 \mathrm{~nm}$, where only a basal lamina was intervening (Fig. 11, 12). They were also directly apposed to juxtamedullary (zonae reticularis and fasciculata profunda) cortical cells and VIP-negative chromaffin cells with an intercellular gap of $15 \mathrm{~nm}$, where no membrane specializations were detected (Fig. 13). Their direct apposition suggests the influence of VIP on the function of these cells in synaptic action.

Immunohistochemistry combined with histochemical staining for acetylcholinesteras (AchE) revealed some of the VIP-ganglion cells to be AchE-positive (Fig. 8, 9). This suggests that VIP and acetylcholine might coexist in some medullary ganglion 
cells, although an immunohistochemical examination using an anti-choline acetyltransferase antibody is crucial to confirm this possibility. To date, no ganglion cells immunoreactive for ENK, NPY, SP, SOM, NT, or CGRP have been reported in the adrenal medulla of any mammalian species.

\section{OCCURRENCE OF PEPTIDES IN NERVE FIBERS}

\section{Opioid peptide}

Knowledge of the involvement of neuropeptides in the innervation of the adrenal gland started with the discovery by SchulTzBERG et al. (1978) of Met-ENK-immunoreactive nerve fibres in the adrenal medulla of rats, guinea pigs and cats. In their study, species difference in the density of networks of the immunoreactive nerve fibers was noted: in rats a sparse but in guinea pigs a denser network of Met-ENK-positive, dot- and fiber-like structures were observed. In cats some immunoreactive fibers were seen, although similar immunoreactive dot- or fiber-like structures were difficult to identify due to the densely packed, strongly ENK-positive chromaffin cells. On the other hand, abundant nerve fibers immunoreactive with anti-Met-ENK-Arg-Gly-Leu antiserum have been demonstrated in the rat adrenal medulla (Fig. 1, 5) (KовауAshi et al., 1983; Kondo et al., 1984). This difference in the frequency of occurrence of the ENKimmunoreactive fibers among three different reports using rats may be due to the specificity of the antisera employed. No nerve fibers showing immunoreactivities with antisera against Leu-ENK or $\alpha$ - or $\beta$-endorphin have been found in the adrenal gland of any species. The absence of nerve fibers immunoreactive for Met- or LeuENK, was reported in the human adrenal medulla (LinNoila et al., 1980).

Immunohistochemical studies at the electron microscopic level (KOBAYASHI et al., 1983a; Kondo et al., 1984) have clearly shown that Met-ENK-Arg-Gly-Leu-immunoreactive nerve fibers in the rat adrenal medulla are characterized by abundant small clear vesicles, $40-50 \mathrm{~nm}$ in diameter, and large granular vesicles, $90-100 \mathrm{~nm}$ in diameter, and that the immunoreactive material is definitely localized in the core of the granular vesicles. The immunoreactive nerve fibers made synaptic contacts with both immuno-positive and negative chromaffin cells (Fig. 15) and ganglion cells. The immunoreactive fibers closely resemble in ultrastructure those of the conventional preganglionic cholinergic nerve fibers in terms of the composition of their vesicles and synaptic morphology. This morphological similarity, together with the frequent occurrence of the immunopositive nerve fibers, suggests that preproenkephalin A and its related opioid peptides may be contained in at least some of the conventional preganglionic cholinergic nerves whose neuronal somata are located in the intermediate gray matter. This possibility has recently been confirmed by us using the simultaneous immunohistochemical staining of one and the same section of the thoracic spinal cord for both Met-ENK-Arg-Gly-Leu and ChAT (Kondo et al., 1984). A substantial number of neuronal somata were immunostained simultaneously by the two antibodies in the nucleus intermediolateralis, the nucleus intercalatus pars paraependymalis and proprius, which are the conventional sympathetic nuclei sending preganglionic axons to innervate the adrenal chromaffin cells. No intimate topographical relation between ENK-nerve fibers and intramedullary blood vessels has been demonstrated and no nerve fibers with ENK-like immunoreactivity have been found in the cortex. 


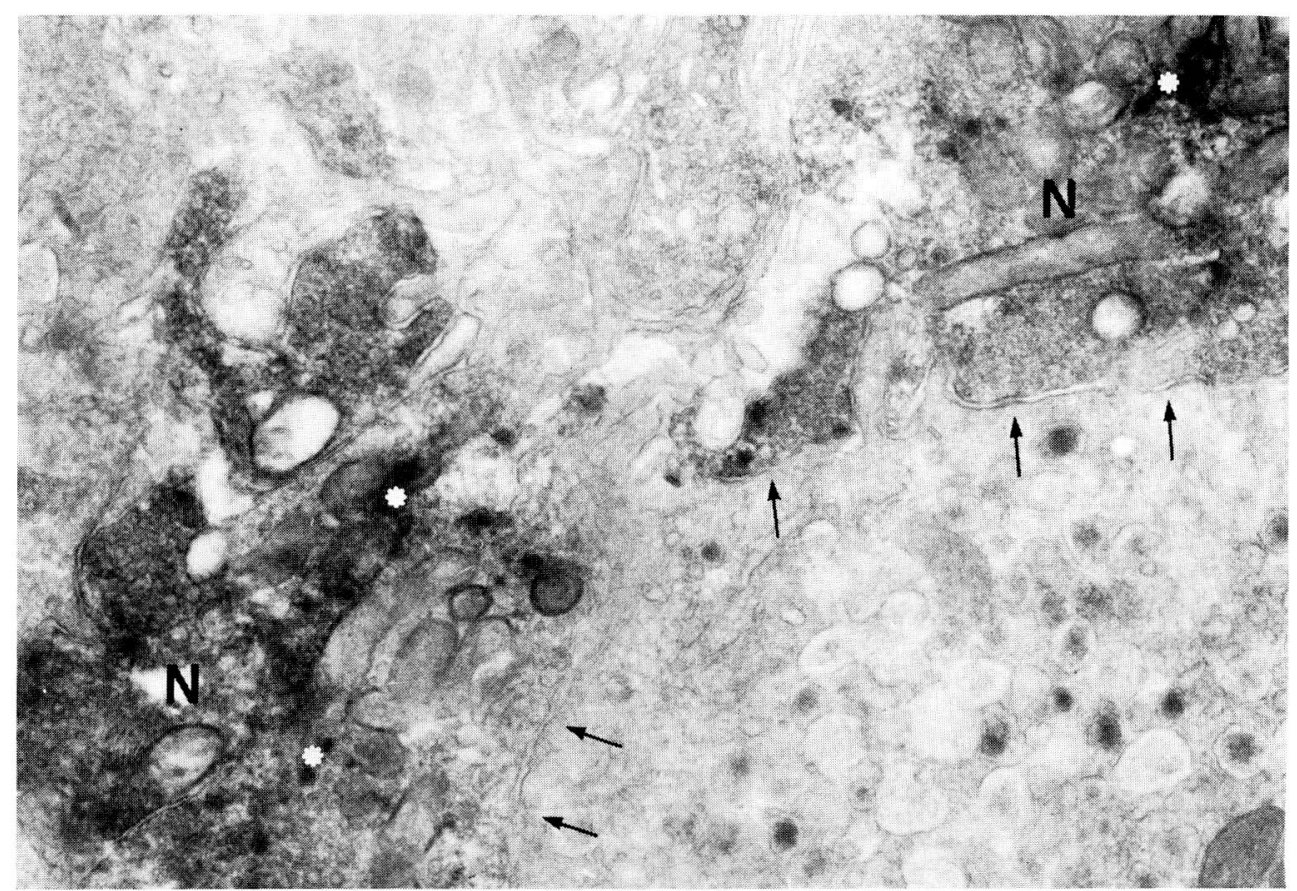

Fig. 15. An electron micrograph showing Met-ENK-Arg-Gly-Leu-immunoreactive nerve fibers $(N)$ in synaptic contact (arrows) with a non-immunoreactive chromaffin cell containing granules with low electron density. The immunoreactive material in the core of the large granular vesicles (asterisks) and in the axoplasm surrounding the vesicles and mitochondria is evident. Note the accumulation of small clear vesicles at the synaptic sites and the displaced localization of the immunoreactive large granular vesicles away from the synaptic sites. $\times 21,000$

\section{NPY}

The occurrence of NPY-immunoreactive nerve fibers was first reported briefly in the adrenal glands of mice, rats, guinea pigs, cats, dogs and horses, and was particularly prominent in rats and cats (VARNDELL et al., 1984). A more detailed immunohistochemical observation of the NPY-nerve fibers in the rat adrenal gland was offered by the present authors at light and electron microscopic levels (KuRAmoto et al., 1985). In our study, a plexus of NPY-immunoreactive nerve fibers with varicosities was present in the subcapsular region; these were often associated with small blood vessels penetrating the capsule of the gland and extended into the zona glomerulosa (Fig. 17). Single NPY-immunoreactive fibers were sparsely distributed in the deeper region of the cortex and in the medulla. The immunoreactive fibers contained abundant small clear vesicles mixed with several small and large granular vesicles. Immunoreactive material appeared in the cores of the granular vesicles, and diffusely in the axoplasm as well. The NPY-fibers were closely apposed to the vascular smooth muscle cells and pericytes; they were sometimes in close apposition to fenestrated endothelial cells with a common basal lamina intervening (Fig. 18, 19). The NPY-fibers also made regular synaptic contacts with cortical cells and occasionally with chromaffin cells. As no ganglion cells with intense NPY-like immunoreactivity were found within the adrenal gland and because a considerable number of postganglionic principal neurons in the celiac ganglion and a small population of neurons in the enteric ganglia have been 


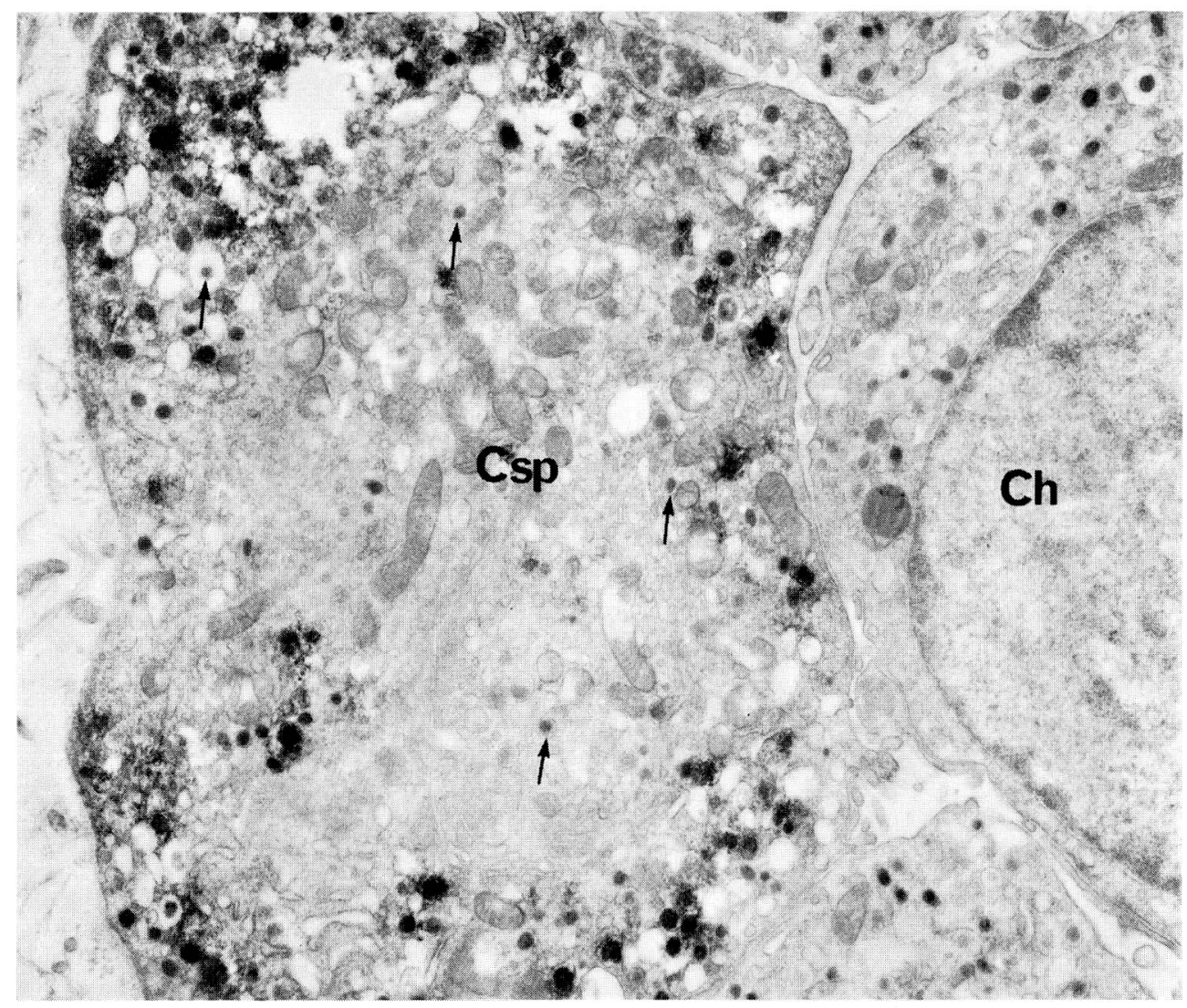

Fig. 16. An electron micrograph showing a substance P-immunoreactive chromaffin cell (Csp) among non-immunoreactive chromaffin cells $(C h)$ in the rat adrenal medulla. The immunoreactive material is well confined to the chromaffin granules. Note the presence of several nonimmunoreactive granules (arrows) mixed with abundant immunoreactive ones. $\times 23,00$

demonstrated to exhibit intense NPY-like immunoreactivity (FurNEss et al., 1983; LUNDBERG et al., 1985), it is probable that the NPY-nerve fibers in the adrenal gland are postganglionic, coming from the celiac ganglion. The findings that the distribution of the NPY-fibers closely paralleled that of NA-containing fibers demonstrated by TH- and DBH-immunostaining (VARNDELL et al., 1984) and that the NPY-fibers contained both small and large granular vesicles support this interpretation regarding the origin of the NPY-fibers. They also indicated the coexistence of NPY and noradrenaline in the nerve fibers.

\section{Substance $P$}

Although a dual localization of substance P-like immunoreactivity in nerve fibers and chromaffin cells has been put forth by radioimmunoassay (Bucsics et al., 1981), a convincing morphological confirmation of this possibility was not available until the light and electron microscopic immunohistochemistry of the rat adrenal medulla was performed by us (Kuramoto et al., 1985). In this study, a few substance P-immunoreactive nerve fibers with varicosities were detected, in addition to a small number of substance P-positive chromaffin cells described in the previous chapter. The immunoreactive 


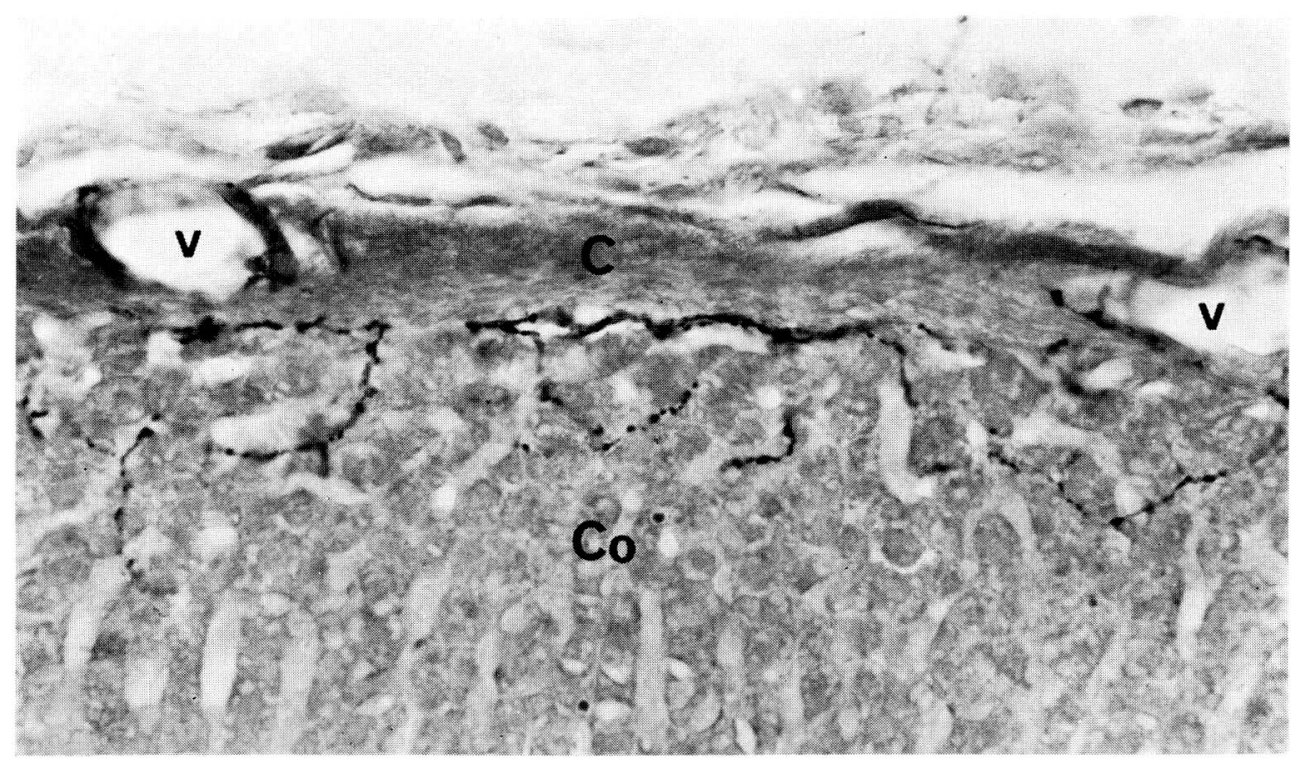

Fig. 17. An immunohistochemical micrcgraph showing a plexus of NPY-positive nerve fibers with a beaded appearance extending underneath the capsule $(C)$ and into the cortical parenchyma $\left(C_{0}\right)$ of the rat adrenal gland. $v$ Intracapsular small blood vessels. $\times 290$

fibers were characterized by the presence of abundant small clear vesicles mixed with a few large granular vesicles. The immunoreactive material was localized in the core of the granules as well as appearing diffusely in the axoplasm. The nerve fibers formed synaptic contacts with non-immunoreactive chromaffin cells. Because of the absence of substance P-positive medullary ganglion cells, the substance P-immunoreactive fibers seemed to be extrinsic in origin, possibly due to the sensory spinal ganglion cells in a similar morphological situation in the autonomic ganglia (KonisHi et al., 1980). Substance P-immunoreactive nerve fibers were also observed to surround a small number of chromaffin cells in the human adrenal medulla (Linnorla et al., 1980). No nerve fibers with substance P-like immunoreactivity have been found in the cortex.

\section{VIP}

An abundant network of varicose nerve fibers exhibiting VIP-like immunoreactivity was first noted in the human adrenal medulla (Linnoila et al., 1980). They were seen in close proximity to chromaffin cells. The occasional occurrence of nerve fibers with VIP-like immunoreactivity was also described in the capsule of the human adrenal gland. Subsequently, a distinct plexus of VIP-immunoreactive fibers was found in the superficial cortex of the rat adrenal gland. A small number of VIP-immunoreactive fibers was also seen in the juxtamedullary cortex and the medulla (Hökfelt et al., 1981; HolzWARTH, 1984). We confirmed these findings at light and electron microscopic levels (KONDO et al., in preparation). In our study, a difference in fine structure between VIP-fibers in the superficial cortex and those in the medulla was noted in the adrenal gland of rats pretreated with colchicine: the former fibers were characterized by abundant small clear vesicles mixed with large granular vesicles, while the latter by abundant small as well as large clear vesicles mixed with large granular vesicles (Fig. 11-13). The occurrence of large clear vesicles seems to be due to the colchicine pretreatment. The immunoreactive material was localized on the core of the granular 


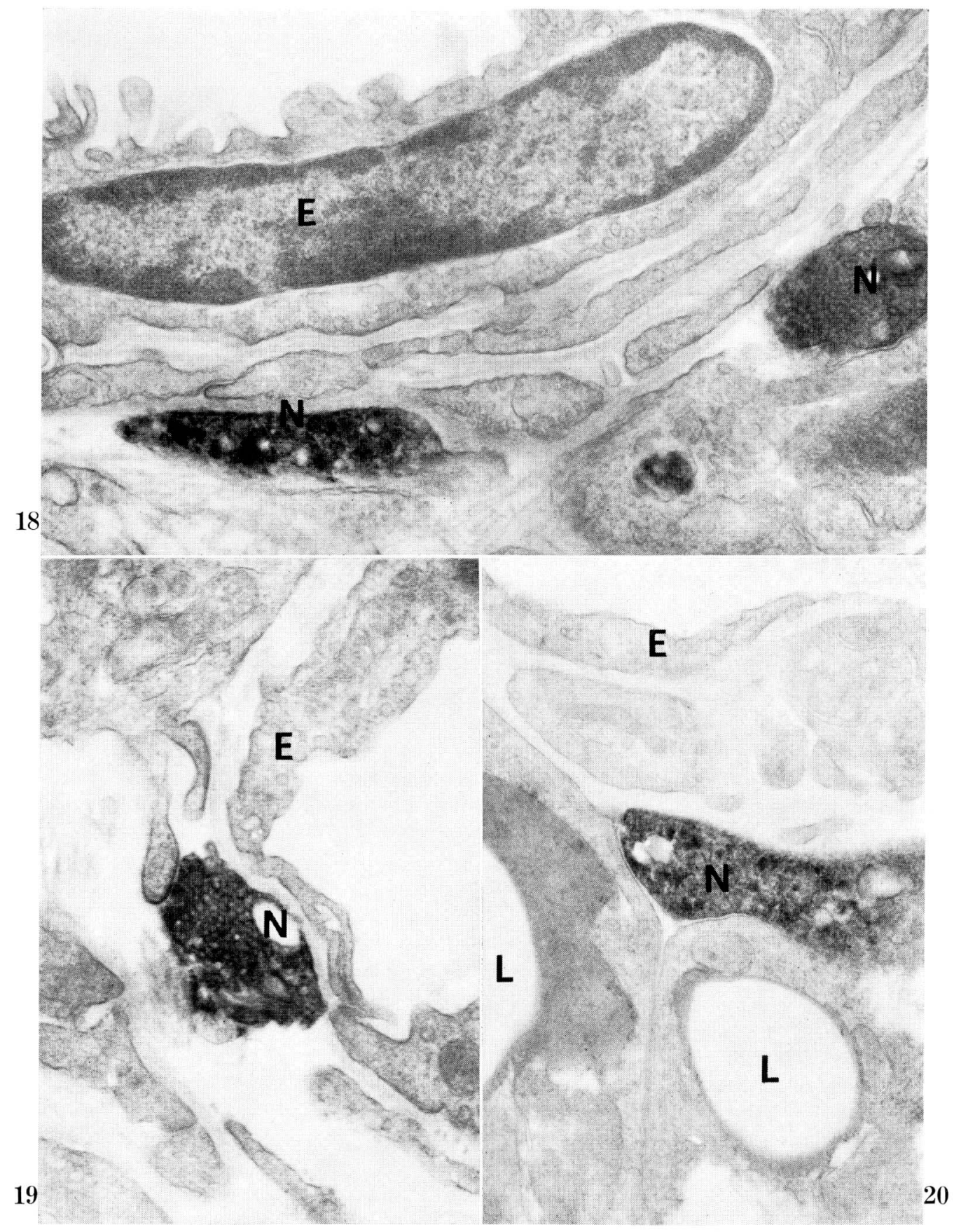

Fig. 18-20. Legends on the opposite page. 
vesicles in both nerves. The immunoreactive nerve fibers in the cortex and the medulla were often in direct contact with their cortical cells (Fig. 20) and chromaffin cells, respectively, without any membrane specializations. They were sometimes closely associated with the vascular smooth muscle cells and pericytes in the superficial cortex, and also seen in close apposition to the fenestrated endothelial cells with only a common basal lamina intervening in the cortex and medulla. Since no distinct continuity has been revealed between VIP-nerve fibers in the superficial cortex and those in the medulla, in spite of the clear evidence for the presence of VIP-immunoreactive medullary ganglion cells, and because there is a clear difference in fine structure in terms of vesicular compositions between VIP-fibers in the cortex and those in the medulla, it is most likely that the VIP-nerve fibers in the superficial cortex are extrinsic in origin, while those in the medulla are processes of medullary ganglion cells. Abundant VIPimmunoreactive neuronal somata located in the enteric ganglia are regarded as a possible source for at least some of the VIP-immunoreactive nerve fibers in the cortex, although detailed retrograde tracing experiments are necessary to confirm this.

\section{Somatostatin}

At present no nerve fibers exhibiting somatostatin-like immunoreactivity have been reported in the adrenal gland of any mammals.

\section{Neurotensin}

The occurrence of neurotensin-immunoreactive nerve fibers has so far been reported only in the adrenal gland of hamsters (PeLto-Huikкo et al., 1985). In the hamster adrenal medulla, neurotensin-immunoreactive fibers were found in the clusters of NAchromaffin cells. About $60-70 \%$ of all terminals in a single NA-cell group were immunopositive for neurotensin, and made synaptic contacts with the chromaffin cells. The immunereactive material was associated with the large granular vesicles, although some staining was also diffusely scattered in the axoplasm. Neurotensinpositive fibers were also seen to make synaptic contacts with medullary ganglion cells. No immunoreactive fibers were seen among the A-chromaffin cells, cortical cells or near blood vessels. Pelto-Huikкo et al. (1985) further performed a denervation experiment in the hamster adrenal medulla, which resulted in the disappearence of the neurotensin-positive nerves. Since the presence of neuronal somata exhibiting neurotensin-like immunoreactivity has been revealed in the spinal cord of guinea pigs (REINECKE et al., 1983), they speculated that the neurotensin-positive nerve fibers in the hamster adrenal medulla might be derived from the spinal cord. This infers that the preganglionic cholinergic nerves may be divided into two groups in terms of their neurotensin content: nerves containing neurotensin-like immunoreactivity innervate NA-cells, while those free of the immunoreactivity innervate both A- and NA-cells. No nerve fibers with neurotensin-like immunoreactivity have been found in the cortex.

Fig. 18 and 19. Electron micrographs showing NPY-immunoreactive nerve fibers $(N)$ in close apposition to pericytes (Fig. 18) and a fenestrated endothelial cell (E) with only a common basal lamina intervening (Fig. 19) in the rat adrenal cortex. The immunoreactive material is localized in the cores of a few large granular vesicles as well as occurring diffusely in the axoplasm, except for the interior of the abundant small clear vesicles. $\times 24,000$

Fig. 20. An electron micrograph showing a VIP-immunoreactive nerve fiber $(N)$ in direct contact (arrows) with cortical cells having lipid granules $(L)$ in the rat adrenal gland. The immunoreactive material is localized in the large granular vesicles as well as in the axoplasm. $E$ endothelial cell. $\times 22,000$ 


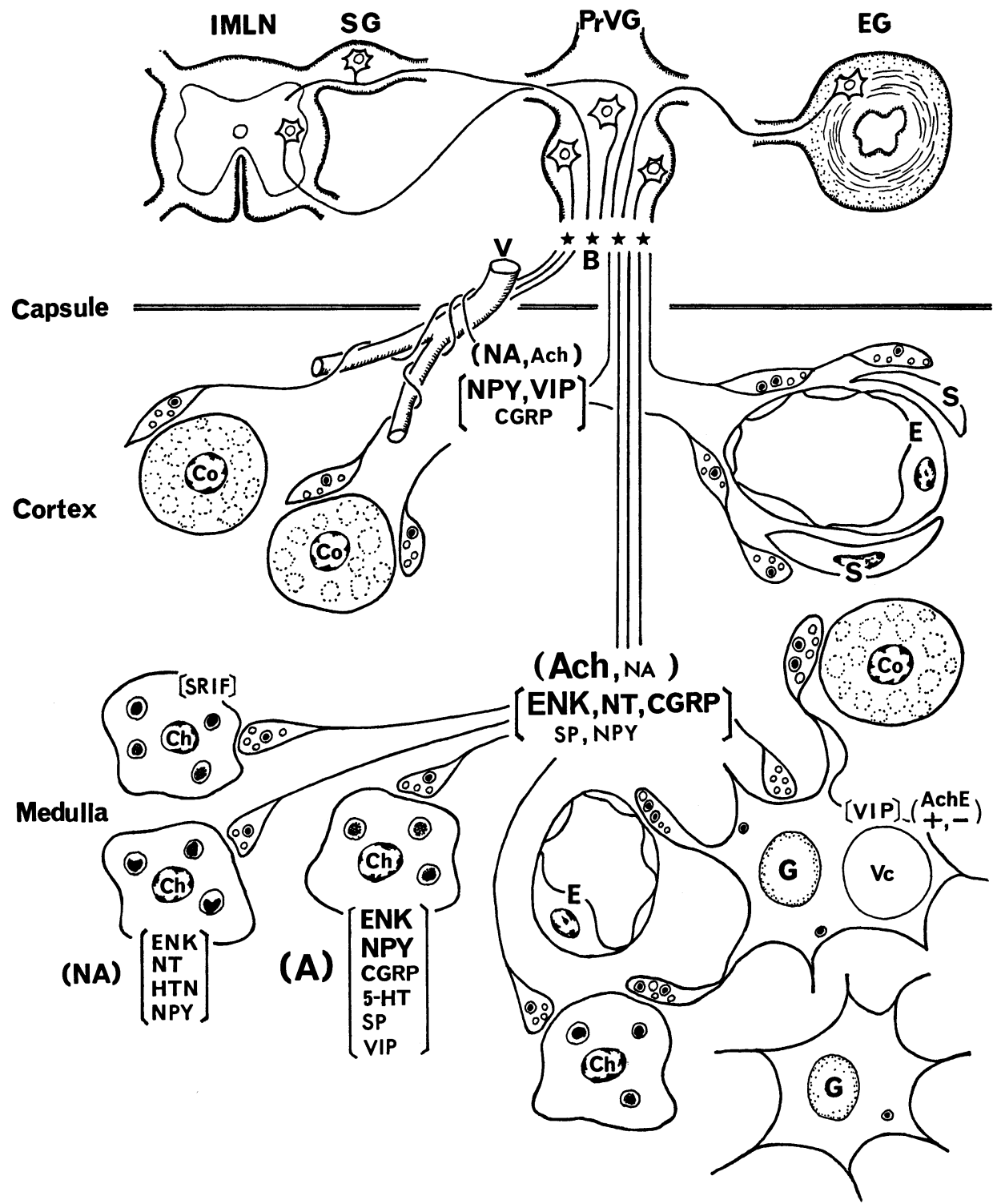

Fig. 21. A diagram showing the present view on localization of neuropeptides and various amines and acetylcholine in the adrenal cortex and medulla, on the innervation of neuropeptide-containing nerves in the adrenal gland, and on possible origins of the intra-adrenal peptide-containing nerves. The size of the abbreviated letters for names of the bioactive substances represents the relative numbers of cellular or neuronal elements containing those substances. As no detailed studies including retrograde labelling have yet been performed on the origin of nerve fibers containing individual bioactive substances, a gap (asterisks) is interposed between nerve bundles $(B)$ penetrating the adrenal capsule and nerves coming from the prevertebral ganglion ( $\operatorname{rr} V G$ ). A adrenaline, Ach acetylcholine, $A c h E$ acetylcholinesterase, $C h$ chromaffin cell, Co cortical cell, CGRP calcitonin gene-related peptide, $E$ endothelial cell, $E N K$ enkephalin, $E G$ enteric ganglion; $G$ intramedullary ganglion cell, $H T N$ histamine, 5-HT 5-hydroxytryptamine, IMLN intermediolateral nucleus, $N A$ noradrenaline, $N T$ neurotensin, $N P Y$ neuropeptide $\mathrm{Y}, S$ smooth muscle cell, $\mathrm{S} G$ spinal ganglion, $S P$ substance $\mathrm{P}$, $S R I F$ somatostatin, $V$ blood vessel, $V c$ vacuole, VIP vasoactive intestinal polypeptide. 


\section{CGRP}

CGRP-immunoreactive nerve fibers with varicosities were first revealed to occur in the adrenal medulla of rats (ROSENFELD et al., 1983). In our recent study of the rat adrenal gland, immunoreactive fibers were found in the superficial cortex and the medulla, where they showed varicosities along their trajectory and surrounded intimately cortical cells, small blood vessels, chromaffin cells and some ganglion cells (KuRAMOTo et al., in preparation). Previous immunohistochemical studies have revealed the occurrence of CGRP-immunoreactive ganglion cells in the spinal ganglia (GIBson et al., 1984). The CGRP-neurons were more numerous than any peptide-immunoreactive neurons, yet were localized in the ganglia. They were shown to include a population of substance P-immunoreactive neurons (Gibson et al., 1984). Therefore, it is likely that the CGRP-positive nerve fibers in the adrenal gland are derived from the spinal ganglia.

\section{GENERAL DISCUSSION}

The discoveries of a large number of neuropeptides in the nervous system initially gave us the impression that nerves containing peptides represent separate entities from neurons containing classical transmitters. However, the present review of the localization of neuropeptides in the adrenal gland offers evidence that all the neuropeptides coexist with CAs, the typical, classical transmitters in the chromaffin cells. The coexistence of peptides with acetylcholine in a substantial number of intra-adrenal neuronal components is also strongly suggested. In studies on the autonomic ganglia, the coexistence of NA with NPY or somatostatin has been proven while that of Ach with VIP has been strongly suggested in the postganglionic neurons (ScHUlTzBERG et al., 1983). It is, therefore, likely that the coexistence neuropeptides with classical transmitters represents the rule rather than the exception, at least in the peripheral nervous system. A new classification of the efferent autonomic nerves into two groups, i.e. 'cholinopeptidergic' and 'adrenopeptidergic' ones proposed by the present author (Kondo, 1983) is also reasonable and useful in the adrenal medulla.

In addition to the coexistence of neuropeptides with classical transmitters, it is now clear that certain populations of chromaffin cells contain multiple bioactive substances including two or more peptides. In one extreme example, ENK, NPY, CGRP, A and 5-HT were all contained in one and the same chromaffin cell. These findings might propose a reclassification of the adrenal chromaffin cells into many subpopulations in terms of combinations of bioactive substances contained, instead of only the current division into two (NA and A) cell types. The same consideration could be applied to the medullary ganglion cells. The appearance of VIP-immunoreactive ganglion cells, some of which were AchE-positive, indicates the presence of at least four subpopulations among the medullary ganglion cells in terms of the presence or absence of VIP and AchE in the cells.

Although peptides and CAs coexist in the adrenal chromaffin cells, their biosynthetic and metabolic pathways seem to be independently regulated. As described in a previous section, the presynaptic splanchnic nerve activity changes the level of ENKlike immunoreactivity in the adrenal chromaffin cells through a trans-synaptic process involving Ach release and nicotinic receptor stimulation (BoHn et al., 1983). A decrease in the splanchnic nerve activity depresses the CA-synthesizing enzymes (PATRICK and 
KIRSCHNER, 1972), whereas it inversely increases the level of ENK-like immunoreactivity. It is well known that glucocorticoid regulates CA-synthesizing enzymes in the adrenal medulla (Wurtman and Axelrod, 1966; Ciaranello et al., 1975, 1976). However, neither glucocorticoid therapy nor hypophysectomy increases ENK-like immunoreactivity in the chromaffin cells (BoHn et al., 1983). On the other hand, not all stimuli elicit such opposite effects on ENK and CA levels. Reserpine treatment, for example, which increases presynaptic nerve activity and the CA-synthesizing enzyme level, also increases ENK-like immunoreactivity (MUELLER et al., 1969; THOENEN et al., 1969; BoHN et al., 1983).

Electron microscopic immunohistochemistry has clarified the fine structural localization of various peptides in chromaffin cells and the nerve fibers innervating them, as reviewed in the previous sections. However, several issues remain to be elucidated. One of these is the fact that not all chromaffin granules are immunolabelled in cells immunoreactive for peptides. One interpretation for this finding is that the antigenic structure of peptides contained in certain chromaffin granules might be modified so markedly during tissue preparations that the granule contents would not be immunolabelled by the individual antisera applied. Alternatively, or in addition, the unlabelled chromaffin granules may represent a subpopulation containing precursors or variants of peptides against which the applied antisera are directed.

Another issue to be elucidated is the fate of the immunoreactive large granular vesicles of peptide-containing nerve fibers terminating on the chromaffin cells. The localization of the immunoreactive material for peptides in the large granular vesicles is a constant feature of any peptide-containing nerve fibers. However, the immunoreactive large granular vesicles are rarely seen subjacent to presynaptic membrane specialization. Instead, they are commonly distributed away from the synaptic sites. This displaced arrangement of the large granular vesicles in the nerve fibers has also been noted in the autonomic ganglia (Kondo and YuI, 1981, $1982 \mathrm{a}$, b; Kondo et al., 1983; Kondo, 1984). By morphological analogy with the immunoreactive chromaffin granules, it seems reasonable to assume that the large granular vesicles in the nerve fibers undergo exocytotic depletion. If this exocytosis really occurs, the granular vesicles should be located close to the plasma membrane of the synaptic site, and then might move far from there during fixation. An alternative explanation for their displaced localization is that the large granular vesicle might be released elsewhere along the presynaptic axolemma rather than into the synaptic cleft. In this regard, a conventional electron microscopic study has pointed out rather paradoxically that the number of the large granular vesicles remains unchanged after electrical stimulation of the nerve fibers (Pollard et al., 1982). This implies the possibility that the immunoreactive, large granular vesicles do not undergo exocytosis but deplete their contents, including peptides, through diacrine secretion into the axoplasm and/or the extracellular space. Further intensive studies are necessary to expedite a conclusion on this issue.

Immunohistochemical studies have clarified the existence of various intraadrenal nerve fibers exhibiting the immunoreactivity for several different peptides. Although it is probable that ENK-fibers are preganglionic cholinergic nerves whose somata are located in the intermediate gray matter of the spinal cord, no detailed examination on the origin of the intraadrenal nerve fiber has been attempted yet. Furthermore, little is known about which peptides are contained in the nerves innervating the intramedullary ganglion cells, except for the occurrence of ENK, neurotensin and CGRP in some nerves in hamsters and rats. This is probably due to the rather sparse distribu- 
tion of ganglion cells in the adrenal medulla. However, since some ganglion cells are known to contain VIP and are in synaptic contact with cortical and chromaffin cells, more than the present amount of attention should be paid to the nerves innervating the ganglion cells.

As described in the previous sections on VIP and NPY, our immuno-electron microscopic studies have disclosed the close apposition of some NPY- and VIP-immunoreactive nerve fibers and ganglionic processes to intra-adrenal fenestrated capillaries with a common basal lamina intervening (КURAмото et al., 1985). This topographical relation of the intra-adrenal nerves to the capillaries closely resembles that of the neurohypophysial axon terminals to the capillaries (Bloom and FAwCETT, 1975). Similar intimate relations between the peripheral nerves and the fenestrated capillaries have previously been noted in the pancreas and adrenal cortex (FujITA and KoBAYASHI, 1974; Kleitman and Holzwarth, 1985). These authors suggested a neurosecretory function for the nerves without any evidence of the chemical substances to be secreted. A neurosecretory nature for the intra-adrenal nerves under the present discussion seems to be more likely because of the clear identification of bioactive, blood-borne substances such as NPY and VIP in the nerves.

All immunohistochemical findings suggest that the peptides may exert their effect in several ways in the adrenal gland: 1 ) by being secreted from chromaffin cells and influencing locally the secretory activity of adjacent chromaffin cells, cortical cells or intra-adrenal vascular smooth muscle cells, pericytes and even endothelial cells by paracrine action; 2) by being secreted from chromaffin cells into intra-adrenal circulation and exerting hemocrine actions locally or systemically (hormonally); or 3 ) by being secreted from chromaffin cells and reversely influencing the innervating nerves including intramedullary ganglion cells at synaptic sites or extrasynaptic sites. The fact that the processes and nerve fibers of intraadrenal ganglion cell somata are often denuded of satellite or Schwann cell sheaths to various extents seems to favor extrasynaptic influence by those bioactive substances secreted from the chromaffin cells. The peptides may also exert their effects further: 4) by being secreted from chromaffin cells and influencing the secretory activity of the same cell through autoregulation; 5 ) by being released from the peptide-containing nerves or ganglion cell processes and influencing chromaffin cells through synaptic or paracrine action; 6 ) by being released from the neuronal elements to function locally or systemically in endocrine action, similar to that in the neurohypophysis; or 7) by being released from the neuronal elements and influencing the intra-adrenal vascular smooth muscle cells, pericytes and even endothelial cells to regulate the intra-adrenal circulation. Furthermore, because of the coexistence and simultaneous release of the bioactive substances, their interaction at target points should be always considered in understanding the physiolopharmacological role of the bioactive substances.

In relation to the possible functions and activities of peptides in the adrenal gland, several physiological findings have recently been reported. Leu- and Met-ENK, substance P and somatostatin inhibited CA secretion linked to the stimulation of nicotinic cholinergic receptors in isolated chromaffin cells of guinea pigs and bovines (LIVETT et al., 1979; Mizobe et al., 1979). Studies with receptor autoradiography and a tissue homogenate receptor binding assay have shown that high levels of specific tritiated neurotensin binding sites are present in the inner layer of the adrenal cortex, with lower amount in the medulla of rats (GOEDERT et al., 1984). This suggests that a circulating neurotensin level could influence steroid secretion from cortical cells, or that neurotensin from the adrenal medulla could influence the adrenal cortex via a retro- 
grade blood flow. VIP has been found to stimulate adenylate cyclase activity and steroid biosynthesis in a mouse tumor adrenal cell line (MORERA et al., 1979; Kowal et al., 1977).

In conclusion, it is clear that the adrenal medulla is the site for the synthesis, storing and secretion of not only CAs but also various peptides. These peptides in the adrenal medulla should not be regarded only as neurotransmitters or modulators for the secretion of CAs, but also per se as hormonal substances to induce systemic effects. A much more complicated mechanism than has been previously known should be considered for understanding the fulfilment of the secretion of both CAs and peptide. The adrenal gland is an organ which plays a far more important role than has been believed in maintaining the internal environment of our bodies.

Acknowledgements. The author wishes to thank Mr. H. Kuramoro for his painstaking collaboration in a series of studies which represent the core of this review. He also gratefully acknowledges Dr. N. YANAIHARA for kindly providing excellent antisera.

\section{REFERENCES}

Adrian, T. E., G. Terenghi, M. J. Brown, J. M. Allen, A. J. Bacarese-Hamilton, J. M. Polak and S. R. Bloom: Neuropeptide Y in pheochromocytomas and ganglioneuroblastomas. Lancet ii: $540-543$ (1983).

Amara, S. G., V. Jonas and M. G. Rosenfeld: Alternative RNA processing in calcitonin gene expression generates mRNAs encoding different polypeptide products. Nature 298: 240-244 (1982).

Baráth, P. and G. Csaba : Effect of pinealectomy on the tritiated serotonin uptake of the adrenal medulla. Hormon Metab. Res. 5: 466-470 (1973).

Bertler, A., A.-M. Rosengren and E. Rosengren : In vivo uptake of dopamine and 5-hydroxytryptamine by adrenal medullary granules. Experientia 16: 418-419 (1960).

Björklund, A. and T. Hökfelt : Handbook of chemical neuroanatomy. Vol. 2. Classical transmitters in the CNS, Part I. Elsevier, Amsterdam-New York-Oxford, 1984.

Bloom, W. and D. W. Fawcett: A textbook of histology, 10th ed. W. B. Saunders Co., PhiladelphiaLondon-Toronto, 1975.

Bohn, M. C., J. A. Kessler, L. Golightly and I. B. Black: Appearance of enkephalin-immunoreactivity in rat adrenal medulla following treatment with nicotinic antagonists or reserpine. Cell Tiss. Ress. 231: 469-479 (1983).

Brazeau, P., W. Vale, K. Burgus, N. Ling, M. Butcher, J. Rivier and R. Guillemin: Hypothalamic polypeptide that inhibits the secretion of immunoreactive pituitary growth hormone. Science 179: 77-79 (1973).

Bryant, M. G., S. R. Bloom, J. M. Polak, R. H. Albuquerque, I. Modlin and A. G. E. Pearse : Possible dual role for vasoactive intestinal peptide as gastrointestinal hormone and neurotransmitter substance. Lancet i: 991-993 (1976).

Bucsics, A., A. Saria and F. Lembeck: Substance P in the adrenal gland: Origin and species distribution. Neuropeptides 1: 329-341 (1981).

Carraway, R. and S. E. Leeman: The isolation of a new hypotensive peptide, neurotensin, from bovine hypothalami. J. Biol. Chem. 248: 6854-6861 (1973).

: The amino acid sequence of a hypothalamic peptide, neurotensin. J. Biol. Chem. 250: 1907-1911 (1975).

Ciaranello R. D., G. F. Wooten and J. Axelrod: Regulation of dopamine- $\beta$-hydroxylase in rat adrenal glands. J. Biol. Chem. 250: 3204-3211 (1975).

: Regulation of rat adrenal dopamine- $\beta$-hydroxylase. II. Receptor interaction in the regulation of enzyme synthesis and degradation. Brain Res. 113: 349-362 (1976). 
Clement-Jones, V., P. J. Lowry, L. H. Rees and G. M. Besser: Met-enkephalin circulates in human plasma. Nature 283: 295-297 (1980).

Corder R., D. F. J. Mason, D. Perrett, P. J. Lowry, V. Clement-Jones, E. A. Linton, G. M. Besser and L. H. Rees: Simultaneous release of neurotensin, somatostatin, enkephalins and catecholamines from perfused cat adrenal glands. Neuropeptides 3: 9-17 (1982).

Coupland, R. E.: Natural history of the chromaffin cell. Longmans, London, 1965.

Csaba, G. and P. Baráth : Localization of ${ }^{3} \mathrm{H}-5-\mathrm{HTP}$ in cells of the adrenal medulla. Z. mikrosk.anat. Forsch. 88: 849-856 (1974).

Csaba, G. and F. Sudár: Localization of radioactively labelled serotonin in the nucleus of adrenal medulla cells. Acta anat. 100: 237-240 (1978).

Dumont M., R. Day and S. Lemaire: Distinct distribution of immunoreactive dynorphin and leucin enkephalin in various populations of isolated adrenal chromaffin cells. Life Sci. 32: 287-294 (1983).

Eiden, L. E., R. L. Eskay, J. Scott, H. Pollard and A. J. Hotchkiss : Primary cultures of bovine chromaffin cells synthesize and secrete vasoactive intestinal polypeptide (VIP) Life Sci. 33 687-693 (1983).

Emson, P. C. and M. E. De Quidt: NPY-a new member of the pancreatic polypeptide family. TINS 7: 31-35 (1984).

Endo, Y. and Y. Ogura: Distribution of histamine in adrenal gland. Jap. J. Pharmacol. 24: 171-173 (1974).

Fahrenkrug, J.: Vasoactive intestinal polypeptide. TINS 3: 1-2 (1980).

Fujita, T. and S. Kobayashi : Proposal of a neurosecretory system in the pancreas. An electron microscopic study in the dog. Arch. histol. jap. 42: 277-295 (1979).

Furness, J. B., M. Costa, P. C. Emson, R. Håkanson, E. Moghimzadeh, F. Sundler, I. L. Taylor and R. E. Chance: Distribution, pathways and reactions to drug treatment of nerves with neuropeptide Y- and pancreatic polypeptide-like immunoreactivity in the guinea-pig digestive tract. Cell Tiss. Res. 234: 71-92 (1983).

Geffard, M., A. McRae-Degueurce and M. L. Souan: Immunocytochemical detection of acetylcholin in the rat central nervous system. Science 229: 77-79 (1985).

Gibson, S. J., J. M. Polak, S. R. Bloom, I. M. Sabate, P. M. Mulderry, M. A. Ghatei, G. P. McGregor, J. F. B. Morrison, J. S. Kelly, R. M. Evans and M. G. Rosenfeld : Calcitonin gene-related peptide immunoreactivity in the spinal cord of man and of eight other species. J. Neurosci. 4: 3101-3111 (1984).

Goedert, M. and P. C. Emson: The regional distribution of neurotensin-like immunoreactivity in central and peripheral tissues of the cat. Brain Res. 272: 291-297 (1983).

Goedert, M., P. W. Mantyh, S. P. Hunt and P. C. Emson: Localization of specific neurotensin binding sites in the rat adrenal gland. Brain Res. 299: 389-392 (1984).

Goedert, M., G. P. Reynolds and P. C. Emson: Neurotensin in the adrenal medulla. Neurosci. Lett. 35: 155-160 (1983).

Govoni, S., I. Hanbauer, T. D. Hexum, H.-Y. Yang, G. D. Kelly and E. Costa : In vivo characterization of the mechanisms that secrete enkephalin-like peptides stored in dog adrenal medulla. Neuropharmacology 20: 639-645 (1981).

Grillo, M. A. : Electron microscopy of sympathetic tissues. Pharmacol. Rev. 18: 387-399 (1966).

Häppölä, O., S. Soinila, H. Päivärinta, T. H. Joh and P. Panula: Histamine-immunoreactive endocrine cells in the adrenal medulla of the rat. Brain Res. 339: 393-396 (1985).

Hervonen, A., M. Pelto-Huikko and I. Linnoila: Ultrastructural localization of enkephalin-like immunoreactivity in the rat adrenal medulla. Amer. J. Anat. 157: 445-448 (1980).

Hexum, T. D., I. Hanbauer, S. Govoni, H.-Y. Yang and E. Costa : Secretion of enkephalin-like peptides from canine adrenal gland following splanchnic nerve stimulation. Neuropeptides 1 : 137-142 (1980).

Hökfelt, T., O. Johansson, Å. Ljungdahl, J. M. Lundberg and M. Schultzberg : Peptidergic neurones. Nature 284: 515-521 (1980).

Hökfelt, T., J. M. Lundberg, M. Schultzberg and J. Fahrenkrug: Immunohistochemical evi- 
dence for a local VIP-ergic neuron system in the adrenal gland of the rat. Acta physiol. scand. 113: 575-576 (1981).

Hökfelt, T., O. Johansson and M. Goldstein : Chemical neuroanatomy of the brain. Science 225: 1326-1333 (1984).

Holzwarth, M. A.: The distribution of vasoactive intestinal peptide in the rat adrenal cortex and medulla. J. autonom. Nerv. Syst. 11: 269-283 (1984).

Hughes, J., T. W. Smith, H. W. Kosterlitz, L. A. Fothergill, B. A. Morgan and H. R. Morris: Identification of two related pentapeptides from the brain with potent opiate agonist activity. Nature 258: 577-579 (1975).

Ito, S., T. Iwanaga, Y. Yamada, T. Suzuki, N. Sudo, T. Momotsu and A. Shibata: Immunohistochemical demonstration of ACTH-like immunoreactivity in the foetal adrenal medulla in the 23rd week of gestation. Acta endocrinol. 97: 412-418 (1981).

Kakidani, H., Y. Furutani, H. Takahashi, M. Noda, Y. Morimoto, Y. Hirose, M. Asai, S. Inayama, S. Nakanishi and S. Numa: Cloning and sequence analysis of cDNA for porcine $\beta$ neo-endorphin/dynorphin precursor. Nature 298: 245-249 (1981).

Kilpatrick, D. L., R. V. Lewis, S. Stein and S. Udenfriend : Release of enkephalin-containing polypeptides from perfused beef adrenal glands. Proc. Nat. Acad. Sci. U.S.A. 77: 7473-7475 (1980).

Kilpatrick, D. L., B. N. Jones, K. Kojima and S. Udenfriend : Identification of the octapeptide [Met] enkephalin-Arg ${ }^{6}-\mathrm{Gly}^{7}-\mathrm{Leu}^{8}$ in extracts of bovine adrenal medullla. Biochem. biophys. Res. Commun. 103: 698-705 (1981)

Kleitman, N. and M. A. Holzwarth: Catecholaminergic innervation of the rat adrenal cortex Cell Tiss. Res. 241: 139-147 (1985).

Kobayashi, S., T. Ohashi, T. Fujita, K. Nakao, T. Yoshimasa, H. Imura, T. Mochizuki, C. Yanaihara, N. Yanaihara and A. A. J. Verhofstad : An immunohistochemical study on the costorage of Met-enkephalin-Arg ${ }^{6}-\mathrm{Gly}^{7}-\mathrm{Leu}^{8}$ and Met-enkephalin-Arg ${ }^{6}-\mathrm{Phe}^{7}$ with adrenaline and/or noradrenaline in the adrenal chromaffin cells of the rat, dog and cat. Biomed. Res. 4: 433-442 (1983a).

Kobayashi, S., T. Uchida, T. Ohashi, T. Fujita, H. Imura, T. Mochizuki, C. Yanaihara and N. Yanaihara: Met-enkephalin-Arg-Gly-Leu-like immunoreactivity in adrenal chromaffin cells and carotid body chief cells of the dog and monkey. Biomed. Res. 4: 201-210 (1983b).

Kondo, H.: Ultrastructure of peptidergic nerves in the mammalian sympathetic ganglia. Biomed. Res. 4, Suppl.: 145-150 (1983).

Kondo, H. and R. Yui : An electron microscopic study on substance P-like immunoreactive nerve fibers in the celiac ganglion of guinea pigs. Brain Res. 222: 134-137 (1981).

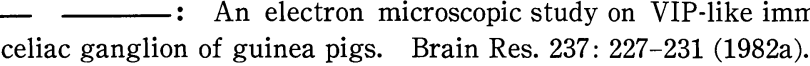
in the celiac ganglion of guinea pigs. Brain Res. 252: 142-145 (1982b)

- : Coexistence of enkephalin and adrenalin in the frog adrenal gland. Histochemistry 80: 243-246 (1984).

Kondo, H., T. Iwanaga and N. Yanaihara : On the occurrence of gastrin releasing peptide (GRP)like immunoreactive nerve fibers in the celiac ganglion of rats. Brain Res. 289: 326-329 (1983).

Kondo, H., H. Kuramoto and T. Iwanaga: Immunohistochemical study on Met-enkephalin-ArgGly-Leu-like immunoreactive nerve fibers in the rat adrenal medulla. Brain Res. 310: 371-375 (1984).

Konishi,, S., A. Tsunoo, N. Yanaihara and M. Otsuka: Peptidergic excitatory and inhibitory synapses in mammalian sympathetic ganglia: Role of substance P and enkephalin. Biomed. Res. 1: 528-536 (1980).

Kowal, J., I. Horst, J. Pensky and M. Alfonzo: A comparison of the effect of ACTH, VIP and cholera toxin on adrenal cAMP and steroid synthesis. Ann. New York Acad. Sci. 297: 314-328 (1977).

Krulich, L., A. P. S. Dhariwal and S. M. McCann: Stimulatory and inhibitory effects of purified hypothalamic extracts on growth hormone release from rat pituitary in vitro. Endocrinolcgy 
83: 783-790 (1973).

Kuramoto, H., H. Kondo and T. Fujita : Substance P-like immunoreactivity in adrenal chromaffin cells and intraadrenal nerve fibers of rats. Histochemistry 82: 507-512 (1985a).

- - N : Neuropeptide tyrosine (NPY)-like immunoreactivity in adrenal chromaffin cells and intraadrenal nerve fibers of rats. Anat Rec. (1985b, in press).

Leboulenger, F., P. Leroux, C. Delarue, M. C. Tonon, Y. Charnay, P. M. Dübois, D. H. Coy and H. Vaudry: Co-localization of vasoactive intestinal peptide (VIP) and enkephalins in chromaffin cells of the adrenal gland of amphibia. Stimulation of corticosteroid production by VIP. Life Sci. 32: 375-383 (1983).

Lembeck, F.: Zur Frage der zentralen Übertragung afferenter Impulse. III. Mitteillung. Naunyn Schmiedeberg's Arch. exp. Pathol Pharmakol. 219: 197-213 (1953).

Lewis, P. R. and C. C. D. Shute: An electron microscopic study of cholinesterase distribution in the rat adrenal medulla. J. Microsc. 89: 181-193 (1969).

Lewis, R. V., A. S. Stern, D. L. Kilpatrick, L. D. Gerber, J. Rossier, S. Stein and S. Udenfriend: Marked increases in large enkephalin-containing polypeptides in the rat adrenal gland following denervation. J. Neurosci. 1: 80-82 (1981).

Linnoila, R. I., R. P. Diaugustine, A. Hervonen and R. J. Miller: Distribution of [Met ${ }^{5}$ - and [Leu ${ }^{5}$-enkephalin-, vasoactive intestinal polypeptide- and substance P-like immunoreactivities in human adrenal gland. Neuroscience 5: 2247-2259 (1980).

Livett, B. G. and D. M. Dean : Distribution of immunoreactive enkephalins in adrenal paraneurons: Preferential localization in varicose processes and terminals. Neuropeptides 1: 3-13 (1980).

Livett, B. G., V. Kozousek, F. Mizobe and D. M. Dean : Substance P inhibits nicotinic activation of chromaffin cells. Nature (London) 278: 256-257 (1979).

Livett, B. G., D. M. Dean, L. G. Whelan, S. Udenfriend and J. Rossier : Co-release of enkephalin and catecholamines from cultured adrenal chromaffin cells. Nature 289: 317-319 (1981).

Livett, B. G., R. Day, R. P. Elde and P. R. C. Howe: Co-storage of enkephalins and adrenaline in the bovine adrenal medulla. Neuroscience $7: 1323-1332$ (1982).

Lundberg, J. M., B. Hamberger, M. Schultzberg, T. Hökfelt, P.-0. Granberg, S. Efendić, L. Terenius, M. Goldstein and R. Luft: Enkephalin- and somatostatin-like immunoreactivities in human adrenal medulla and pheochromocytoma. Proc. Nat. Acad. Sci. U.S.A. 76: 4079-4083 (1979).

Lundberg, J. M., А. Rökaeus, T. Hökfelt, S. Rosell, M. Brown and M. Goldstein : Neurotensin-like immunoreactivity in the preganglionic sympathetic nerves and in the adrenal medulla of the cat. Acta. physiol. scand. 114: 153-155 (1982).

Lundberg, J. M. A. Änggård, J. Pernow and T. Hökfelt : Neuropeptide Y, substance P and VIPimmunoreactive nerves in cat spleen in relation to autonomic vascular and volume control. Cell Tiss. Res. 239: 9-18 (1985).

Mattiasson, A., E. Ekblad, F. Sundler and B. Uvelius: Origin and distribution of neuropeptide Y-, vasoactive intestinal polypeptide- and substance P-containing nerve fibers in the urinary bladder of the rat. Cell Tiss. Res. 239: 141-146 (1985).

Mizobe, F., F. Kozousek, D. M. Dean and B. G. Livetti : Pharmacological characterization of adrenal paraneurons: substance $\mathrm{P}$ and somatostatin as inhibitory modulators of the nicotine response. Brain Res. 178: 555-556 (1979).

Morerra, A. M., A. M. Cathiard, M. Laburthe and J. M. Saez : Interaction of vasoactive intestinal peptide (VIP) with a mouse adrenal cell line (Y-1): Specific binding and biological effects. Biochem. biophys. Res. Commun. 90: 78-85 (1979).

Mueller R. A., H. Thoenen and J. Axelrod: Increase in tyrosine hydroxylase activity after reserpine administration. J. Pharmacol. exp. Therap. 169: 74-79 (1969).

Mulderry, P. K., M. A. Ghatei, J. Rodrigo, J. M. Allen, M. G. Rosenfeld, J. M. Polak and S. R. Bloom: Calcitonin gene-related peptide in cardiovascular tissues of the rat. Neuroscience 14: 947-954 (1985).

Mutt, V. and S. I. Said: Structure of the porcine vasoactive intestinal octacosapeptide: The amino acid sequence. Use of kallikrein in its determination. Eur. J. Biochem. 42: 581-589 (1974). 
Nakanishi, S., A. Inoue, T. Kita, M. Nakamura, A. C. Y. Chang, S. N. Cohen and S. Numa: Nucleotide sequence of cloned cDNA for bovine corticotropin- $\beta$-lipotropin precursor. Nature 278: 423-427 (1979).

Noda, M., Y. Furutani, H. Takahashi, M. Toyosato, T. Hirose, S. Inayama, S. Nakanishi and S. Numa: Cloning and sequence analysis of cDNA for bovine adrenal preproenkephalin. Nature 295: 202-206 (1982).

Otsuka, M. and S. Konishi : Release of substance P-like immunoreactivity from isolated spinal cord of newborn rat. Nature 264: 83-84 (1976).

Patrick, R. L. and N. Kirschner: Developmental changes in rat adrenal tyrosine hydroxylase, dopamine- $\beta$-hydroxylase and catecholamine levels: Effect of denervation. Devel. Biol. 29: 204$213(1972)$

Pelto-Huikko, M., T. Salminen and A. Hervonen: Enkephalin-like immunoreactivity is restricted to the adrenaline cells in the hamster adrenal medulla. Histochemistry 73: 493-497 (1982).

Pelto-Huikko, M., T. Salminen, M. Partanen, M. Toivanen and A. Hervonen : Immunohistochemical localization of neurotensin in hamster adrenal medulla. Anat. Rec. 211: 458-464 (1985).

Pollard, R. M., M. Fillenz and P. Kelly: Parallel changes in ultrastructure and noradrenaline content of nerve terminals in rat vas deferens following transmitter release. Neuroscience 7 : 1623-1629 (1982).

Reineke, M., W. G. Forssman, G. Thiekötter and J. Triepel : Localization of neurotensinimmunoreactivity in the spinal cord and peripheral nervous system of guinea pig. Neurosci. Lett. 37 : 37-42 (1983).

Role, L. W., S. E. Leeman and R. L. Perlman : Somatostatin and substance P inhibit catecholamine secretion from isolated cells of guinea-pig adrenal medulla. Neuroscience 6: 1813-1821 (1981).

Rosenfeld, M. G., S. G. Mermod, L. W. Amara, P. E. Swanson, J. Sawchenko, W. W. V. Rivier and R. M. Evans: Production of a novel neuropeptide encoded by the CT gene via tissue-specific RNA processing. Nature 304: 129-135 (1983).

Saria, A., S. P. Wilson, A. Molnar, O. H. Viveros and F. Lembeck : Substance P and opiate-like peptide in human adrenal medulla. Neurosci. Lett. 20: 195-200 (1980).

Schultzberg, M., J. M. Lundberg, T. Hökfelt, L. Terenius, J. Brandt, R. P. Elde and M. Goldstein : Enkephalin-like immunoreactivity in gland cells and nerve terminals of the adrenal medulla. Neuroscience 3: 1169-1186 (1978).

Schultzberg, M., T. Hökfelt, J. M. Lundberg, C. J. Dalsgaard and L.-G. Elfvin: Transmitter histochemistry of autonomic ganglia. In: (ed. by) L.-G. Elfvin: Autonomic ganglia. John Wiley \& Sons, 1983 (p. 205-233).

Siegel, R. E., L. E. Eiden and R. M. Pruss : Multiple populations of neuropeptide-containing cells in cultures of the bovine adrenal medulla. Devel. Brain Res. 17: 267-270 (1985).

Steinbusch, H. W. M., A, A. J. Verhofstad and H. W. J. Joosten : Localization of serotonin in the central nervous system by immunohistochemistry: Description of a specific and sensitive technique and some applications. Neuroscience 3: 811-819 (1978).

Stern, A. S., R. V. Lewis, S. Kimura, J. Rossier, L. D. Gerber, L. Brink, S. Stein and S. Udenfriend: Isolation of the opioid heptapeptide Met-enkephalin ( $\mathrm{Arg}^{6}, \mathrm{Phe}^{7}$ ) from bovine adrenal medullary granules and striatum. Proc. Nat. Acad. Sci. U.S.A. 76: 6680-6683 (1979).

Storm-Mathisen, J., A. K. Leknes, A. T. Bore, J. L. Vaaland, P. Edminson, F.-M. S. Haug and O. P. Otterson: First visualization of glutamate and GABA in neurones by immunocytochemistry. Nature (London) 301: 517-520 (1983).

Sudár, F. and G. Csaba: Localization of ${ }^{3} \mathrm{H}$-serotonin in the adrenal medullary cells of newborn rats. Acta morphol. hung. 27: 83-87 (1979).

Tatemoto, K.: Neurepeptide Y: Complete amino acid sequence of the brain peptide. Proc. Nat. Acad. Sci. U.S.A. 79: 5385-5489 (1982).

Tatemoto, K., M. Carlqist and V. Mutt: Neuropeptide Y-a novel brain peptide with structural similarities to peptide YY and pancreatic polypeptide. Nature 296: 659-660 (1982). 
Terenghi, G., J. M. Polak, I. M. Varndell, Y. C. Lee, J. Wharton and S. R. Bloom: Neurotensin-like immunoreactivity in a subpopulation of noradrenaline-containing cells of the cat adrenal gland. Endocrinology 112: 226-233 (1983).

Thoenen, H., R. A. Mueller and J. Axelrod: Increased tyrosine hydroxylase activity after druginduced alteration of sympathetic transmission. Nature 221: 1264 (1969).

Unsicker, K. : Über die Ganglienzellen im Nebennierenmark des Goldhamsters (Mesocricetus auratus). Ein Beitrag zur Frage der peripheren Neurosekretion. Z. Zellforsch. 76: 187-219 (1967).

Unisicker, K., U. Zwarg and O. Habura: Electron microscopic evidence for the formation of synapses and synaptoid contacts in adrenal medullary grafts. Brain Res. 120: 533-539 (1977).

Varndell, I. M., F. J. Tapia, J. DeMey, R. A. Rush, S. R. Bloom and J. M. Polak: Electron immunocytochemical localization of enkephalin-like material in catecholamin-containing cells of the carotid body, the adrenal medulla, and in phenochromocytomas of man and other mammals. J. Histochem. Cy tochem. 30: 682-690 (1982).

Varndell, I. M., J. M. Polak, J. M. Allen, G. Terenghi and S. R. Bloom : Neuropeptide tyrosine (NPY) immunoreactivity in norepinephrine-containing cells and nerves of mammalian adrenal gland. Endocrinologia. 114: 1460-1462 (1984).

Verhofstad, A. A. J., H. W. M. Steinbusch, B. Penke, J. Varga and H. W. J. Joosten : Use of antibodies to norepinephrine and epinephrine in immunohistochemistry. In: (ed. by) O. Eränkö, S. Soinila and H. Päivärinta: Histochemistry and cell biology of autonomic neurons, SIF cells, and paraneurons (Adv. biochem. Psychopharmacol. Vol. 25). Raven Press, New York, 1980 (p. 185-193).

Verhofstad, A. A. J. and G. Jonsson: Immunohistochemical and neurochemical evidence for the presence of serotonin in the adrenal medulla of the rat. Neuroscience 10: 1443-1453 (1983)

Viveros, O. H., E. J. Diliberto Jr., E. Hazum and K.-J. Chang: Opiate-like materials in the adrenal medulla: Evidence for storage and secretion with catecholamines. Mol. Pharmacol. 16: 1101-1108 (1979). age, secretion and regulation of synthesis. In: (ed, dy peptides and neuronal communication. (Adv. biochem. Psychopharmacol. Vol. 22) Raven Press, New York, 1980 (p. 191-204).

Viveros, $\mathbf{O}$. H. and S. P. Wilson: The adrenal chromaffin cells as a model to study the co-secretion of enkephalins and catecholamines. J. Auton. Nerv. Syst. 7: 41-58 (1983).

Wurtman, R. J. and J. Axelrod: Control of enzymatic synthesis of adrenaline in the adrenal medulla by adrenal cortical steroids. J. biol. Chem. 241: 2301-2305 (1966).

\author{
近藤尚武 \\ 干951 新潟市旭町通 1 \\ 新潟大学医学部 \\ 第三解剖学教室
}

Dr. Hisatake Kondo

Department of Anatomy

Niigata University School of Medicine

Asahimachi, Niigata, 951 Japan 